\title{
Chemical structures of macrocyclic bis(bibenzyls) isolated from liverworts (Hepaticae)
}

\author{
Yoshinori Asakawa*, Masao Toyota, Motoo Tori and Toshihiro Hashimoto \\ Faculty of Pharmaceutical Sciences, Tokushima Bunri University, Yamashiro-cho, Tokushima 770-8514, \\ Japan \\ Tel.: +81 88622 9611; Fax: +81 655 3051; E-mail: asakawa@ph.bunri-u.ac.jp
}

\section{Dedicated to the memory of Dr. Piet Leclercq}

\begin{abstract}
Liverworts (Hepaticae) produce a number of macrocyclic bis(bibenzyls) which show interesting biological activity and are of very valuable for the chemosystematic study of liverworts. The structural elucidation of these characteristic natural products are reviewed.
\end{abstract}

\section{Introduction}

The bryophytes [Musci (mosses), Hepaticae (liverworts) and Anthocerotae (hornworts)], which are the spore-forming terrestrial green plants are morphologically placed between the algae and the pteridophytes (fern) and there are ca. 24,000 species in the world. Among the bryophytes almost all liverworts possess cellular oil bodies which are very important markers for the classification in the Hepaticae. Müller [1] reported that oil bodies are composed of sesquiterpenes. In 1967, Huneck and Klein [2] found that some liverworts produced ent-sesquiterpenoids. On the other hand, the mosses and the hornworts do not contain oil bodies. It has been demonstrated that most of the Hepaticae contain mainly mono-, sesqui- and diterpenoids and lipophilic aromatic compounds [bibenzyls, bis(bibenzyls), naphthalenes, phthalides, isocoumarins, cinnamates, benzoates, benzyl and $\beta$-phenethyl acrylates and prenyl indoles etc.] which constitute the oil bodies [3-5]. The characteristic components of the Musci are highly unsaturated fatty acids and triterpenoids. The neolignan is the most important chemical marker of the Anthocerotae. Some liverworts show characteristically fragrant odors and intensely hot and bitter or saccharine-like taste. Generally, liverworts are not damaged by bacteria, fungi, insects, snails, slugs and other small animals. Furthermore, some liverworts cause intense allergenic contact dermatitis and allelopathy. Some bryophytes growing in lake, river and pond accumulate heavy metals. Many bryophyte species have been used as medicinal plants, particularly in China [6]. However, only tasting substances and allergens of some species have been fully investigated. We have been interested in these biologically

\footnotetext{
${ }^{*}$ Corresponding author.
} 
Table 1

The liverworts which contain cyclic bis(bibenzyls)

\begin{tabular}{|c|c|c|}
\hline Cyclic bis(bibenzyls) & Species & References \\
\hline Riccardin A (1a) & Riccardia multifida & {$[4,12,13 \mathrm{a}, 13 \mathrm{~b}, 13 \mathrm{c}]$} \\
\hline \multirow[t]{2}{*}{ Riccardin B (2) } & Riccardia multifida & {$[4,12,13 a, 13 c]$} \\
\hline & Preissia quadrata & {$[51]$} \\
\hline \multirow[t]{11}{*}{ Riccardin C (3) } & Blasia pussila & [18-20] \\
\hline & Dumortiera hirsuta & {$[22]$} \\
\hline & Marchantia paleacea var. & {$[21]$} \\
\hline & diptera & \\
\hline & Marchantia palmata & {$[16]$} \\
\hline & Marchantia polymorpha & {$[15,16]$} \\
\hline & Monoclea forsteri & {$[17]$} \\
\hline & Plagiochasma petrospermum & {$[23]$} \\
\hline & Plagiochasma rupestre & {$[24]$} \\
\hline & Reboulia hemisphaerica & {$[14]$} \\
\hline & Ricciocarpos natans & [25] \\
\hline Riccardin D (4) & Monoclea forsteri & {$[17]$} \\
\hline Riccardin E (5) & Monoclea forsteri & {$[17]$} \\
\hline \multirow{2}{*}{ Riccardin F (6) } & Blasia pussila & [18-20] \\
\hline & Marchantia tosana & [26a] \\
\hline Riccardin G (7) & Marchantia chenopoda & {$[27]$} \\
\hline \multirow[t]{6}{*}{ Marchantin A (8a) } & $\begin{array}{l}\text { Marchantia paleacea var. } \\
\text { diptera }\end{array}$ & {$[26 \mathrm{a}, 26 \mathrm{c}]$} \\
\hline & Marchantia plicata & [35] \\
\hline & Marchantia polymorpha & {$[12,15,26 \mathrm{a}, 28-30 \mathrm{a}]$} \\
\hline & Marchantia tosana & [26a] \\
\hline & Plagiochasma appendiculatum & [26b] \\
\hline & Wiesnerella denudata & {$[36]$} \\
\hline \multirow[t]{7}{*}{ Marchantin B (9) } & $\begin{array}{l}\text { Marchantia paleacea var. } \\
\text { diptera }\end{array}$ & [26a] \\
\hline & Marchantia palmata & {$[15]$} \\
\hline & Marchantia polymorpha & {$[12,15,26 \mathrm{a}, 28-30 \mathrm{a}]$} \\
\hline & Marchantia tosana & [26a] \\
\hline & Plagiochasma appendiculatum & {$[26 \mathrm{~b}]$} \\
\hline & Plagiochasma rupestre & [24] \\
\hline & Wiesnerella denudata & [36] \\
\hline \multirow[t]{9}{*}{ Marchantin C (10) } & Dumortiera hirsuta & {$[21,22]$} \\
\hline & $\begin{array}{l}\text { Marchantia paleacea var. } \\
\text { diptera }\end{array}$ & [26a] \\
\hline & Marchantia polymorpha & {$[12,15,26 a, 28-30 a]$} \\
\hline & Monoclea forsteri & {$[42]$} \\
\hline & Plagiochasma appendiculatum & {$[26 \mathrm{~b}]$} \\
\hline & Plagiochila sciophila & {$[43]$} \\
\hline & Reboulia hemisphaerica & {$[34,47]$} \\
\hline & Riccardia nagasakiensis & {$[13 b]$} \\
\hline & Schistochila glaucescens & {$[50]$} \\
\hline
\end{tabular}


Table 1

(Continued).

\begin{tabular}{|c|c|c|}
\hline Cyclic bis(bibenzyls) & Species & References \\
\hline Marchantin C & Reboulia hemisphaerica & [34] \\
\hline \multicolumn{3}{|l|}{ Dimethyl ether (11) } \\
\hline \multirow[t]{2}{*}{ Marchantin D (12) } & $\begin{array}{l}\text { Marchantia paleacea var. } \\
\text { diptera }\end{array}$ & [26a] \\
\hline & Marchantia polymorpha & {$[12,15,26 a, 28-30 a]$} \\
\hline \multirow[t]{2}{*}{ Marchantin E (13) } & $\begin{array}{l}\text { Marchantia paleacea var. } \\
\text { diptera }\end{array}$ & [26a] \\
\hline & Marchantia polymorpha & {$[2,15,26 a, 28-30 a]$} \\
\hline \multirow[t]{2}{*}{ Marchantin F (14) } & $\begin{array}{l}\text { Marchantia paleacea var. } \\
\text { diptera }\end{array}$ & [26a] \\
\hline & Marchantia polymorpha & {$[12,15,26 \mathrm{a}, 28-30 \mathrm{a}]$} \\
\hline \multirow[t]{3}{*}{ Marchantin G (15) } & $\begin{array}{l}\text { Marchantia paleacea var. } \\
\text { diptera }\end{array}$ & [26a] \\
\hline & Marchantia palmata & {$[15]$} \\
\hline & Marchantia polymorpha & {$[12,15,26 \mathrm{a}, 28-30 \mathrm{a}]$} \\
\hline \multirow[t]{4}{*}{ Marchantin H (16) } & Marchantia diptera & {$[46]$} \\
\hline & Marchantia polymorpha & {$[16]$} \\
\hline & Plagiochasma repestre & [31] \\
\hline & Plagiochila sciophila & {$[43]$} \\
\hline Marchantin I (17) & Riccardia multifida & [31] \\
\hline Marchantin J (18a) & Marchantia polymorpha & [29] \\
\hline \multirow[t]{2}{*}{ Marchantin K (18b) } & Marchantia polymorpha & [29] \\
\hline & Plagiochasma rupestre & {$[24]$} \\
\hline Marchantin L (19) & Marchantia polymorpha & [29] \\
\hline Marchantin M (20) & Reboulia hemisphaerica & {$[44]$} \\
\hline Marchantin N (21) & Reboulia hemisphaerica & {$[44]$} \\
\hline \multirow[t]{2}{*}{ Isomarchantin C (22) } & Dumortiera hirsuta & [21a] \\
\hline & Mylia nuda & {$[40,41]$} \\
\hline \multirow[t]{6}{*}{ Isoriccardin C (23) } & Bryopteris filicina & [39] \\
\hline & Dumortiera hirsuta & [21] \\
\hline & Monoclea forsteri & {$[42]$} \\
\hline & Plagiochasma rupestre & {$[22,45]$} \\
\hline & Plagiochila sciophila & {$[43]$} \\
\hline & Reboulia hemisphaerica & {$[44]$} \\
\hline Marchantin O (24) & Reboulia hemisphaerica & {$[44,46,47]$} \\
\hline Marchantin P (25) & Marchantia chenopoda & {$[27]$} \\
\hline \multirow[t]{2}{*}{ Marchantiaquinone (26) } & Mannia subpilosa & [34] \\
\hline & Reboulia hemisphaerica & {$[44,47]$} \\
\hline Ptychantol A (27) & Ptychantus striatus & {$[48]$} \\
\hline Ptychantol B (28) & Ptychantus striatus & {$[48]$} \\
\hline Ptychantol C (29) & Ptychantus striatus & {$[48]$} \\
\hline \multirow[t]{2}{*}{ Pakyonol (30) } & Mannia fragrans & [49] \\
\hline & Plagiochasma petrospermum & {$[24 \mathrm{a}]$} \\
\hline Neomarchantin A (31) & Schistochila glaucescens & {$[50]$} \\
\hline
\end{tabular}


Table 1

(Continued).

\begin{tabular}{|c|c|c|}
\hline$\overline{\text { Cyclic bis(bibenzyls) }}$ & Species & References \\
\hline & Monoclea forsteri & {$[42]$} \\
\hline & Preissia quadrata & [51] \\
\hline Neomarchantin B (32) & Schistochila glaucescens & {$[50]$} \\
\hline Plagiochin A (33) & Plagiochila fruticosa & [43] \\
\hline Plagiochin B (34) & Plagiochila fruticosa & {$[43]$} \\
\hline Plagiochin C (35) & Plagiochila fruticosa & [43] \\
\hline Plagiochin D (36) & Plagiochila fruticosa & [43] \\
\hline \multirow[t]{3}{*}{ Isoplagiochin A (37) } & Plagiochila fruticosa & {$[18,52-55]$} \\
\hline & Unidentified Plagiochila sp. & [57] \\
\hline & Heteroscyphus planus & {$[56]$} \\
\hline Isoplagiochin B (38) & Plagiochila fruticosa & {$[18,52-55]$} \\
\hline \multirow[t]{2}{*}{ Isoplagiochin C (39) } & Plagiochila fruticosa & {$[18,52-55]$} \\
\hline & Herbertus sakuraii & [59] \\
\hline \multirow[t]{2}{*}{ Isoplagiochin D (40) } & Plagiochila fruticosa & {$[18,52-55]$} \\
\hline & Herbertus sakuraii & [59] \\
\hline Plunusin (41) & Heteroscyphus planus & {$[56]$} \\
\hline Isoplagiochin E (42) & Unidentified Plagiochila sp. & [57] \\
\hline Isoplagiochin F (43) & Unidentified Plagiochila sp. & [57] \\
\hline 12-Chloroisoplagiochin D (44) & Unidentified Plagiochila sp. & [57] \\
\hline Bazzanin A (45) & Bazzania trilobata & {$[58]$} \\
\hline Bazzanin B (46) & Bazzania trilobata & {$[58]$} \\
\hline Bazzanin C (47) & Bazzania trilobata & {$[58]$} \\
\hline Bazzanin D (48) & Bazzania trilobata & {$[58]$} \\
\hline Bazzanin E (49) & Bazzania trilobata & [58] \\
\hline Bazzanin F (50) & Bazzania trilobata & [58] \\
\hline Bazzanin G (51) & Bazzania trilobata & {$[58]$} \\
\hline Bazzanin H (52) & Bazzania trilobata & [58] \\
\hline Bazzanin I (53) & Bazzania trilobata & [58] \\
\hline 12,6'-Dichloroiso- & Bazzania trilobata & [58] \\
\hline plagiochin D (54) & Bazzania trilobata & [58] \\
\hline Bazzanin K (55) & Bazzania trilobata & [58] \\
\hline $\begin{array}{l}\text { 12,10'-Dichloroiso- } \\
\text { plagiochin C (56) }\end{array}$ & Herbertus sakuraii & [59] \\
\hline $\begin{array}{l}\text { 2,12-Dichloroiso- } \\
\text { plagiochin D (57) }\end{array}$ & Herbertus sakuraii & [59] \\
\hline $\begin{array}{l}\text { 12, } 7^{\prime} \text {-Dichloroiso- } \\
\text { plagiochin D (58) }\end{array}$ & Herbertus sakuraii & [59] \\
\hline Pusilatin A (60a) & Blasia pussila & {$[19,20,53,54]$} \\
\hline Pusilatin B (61) & Blasia pussila & {$[19,20,53,54]$} \\
\hline Pusilatin C (61) & Blasia pussila & {$[19,20,53,54]$} \\
\hline Pusilatin D (63) & Blasia pussila & {$[19,20,53,54]$} \\
\hline Pusilatin E (64) & Riccardia multifida & {$[60]$} \\
\hline Cavicularin (65) & Cavicularia densa & {$[61]$} \\
\hline
\end{tabular}


Table 2

${ }^{1} \mathrm{H}$ NMR spectral data for riccardins A (1a), B (2) and C (3)

\begin{tabular}{llll}
\hline & \multicolumn{1}{c}{$(\mathbf{1 a})^{*}$} & \multicolumn{1}{c}{$(\mathbf{2})^{*}$} & $(3)^{* *}$ \\
\hline 2,6 & $6.70(\mathrm{br})^{\mathrm{a}}$ & $6.63(\mathrm{~d}, 8.6)$ & $6.72-6.80^{\mathrm{b}}$ \\
3 & $6.75(\mathrm{br})^{\mathrm{a}}$ & $6.70(\mathrm{~d}, 8.6)$ & $6.87(\mathrm{br} \mathrm{s})$ \\
5 & $6.83(\mathrm{br})^{\mathrm{a}}$ & $6.70(\mathrm{~d}, 8.6)$ & $6.87(\mathrm{br} \mathrm{s})$ \\
7 & $2.88(\mathrm{~m})$ & $2.78(\mathrm{~m})$ & $2.88(\mathrm{~m})$ \\
& & & $2.95(\mathrm{~m})$ \\
8 & $2.65(\mathrm{~m})$ & $2.78(\mathrm{~m})$ & $2.23-2.75^{\mathrm{b}}$ \\
& & & $3.03(\mathrm{~m})$ \\
10 & $6.98(\mathrm{~d}, 2.9)$ & $7.06(\mathrm{ddd}, 7.8,2.4,0.8)$ & $6.96(\mathrm{~d}, 2.9)$ \\
11 & & $7.32(\mathrm{dd}, 7.8,7.8)$ & $6.79(\mathrm{dd}, 8.6,2.9)$ \\
12 & $6.82(\mathrm{dd}, 8.5,2.9)$ & $6.93(\mathrm{ddd}, 7.8,2.4,0.8)$ & $7.03(\mathrm{~d}, 8.6)$ \\
13 & $7.05(\mathrm{~d}, 8.5)$ & $6.80(\mathrm{dd}, 8.1,1.5)$ & $5.35(\mathrm{~d}, 2.0)$ \\
14 & & $6.03(\mathrm{dd}, 2.4,2.4)$ & $6.73(\mathrm{dd}, 8.1,2.0)$ \\
$3^{\prime}$ & $5.33(\mathrm{~d}, 1.9)$ & $6.02(\mathrm{~d}, 2.1)$ & $6.92(\mathrm{~d}, 8.1)$ \\
$5^{\prime}$ & $6.69(\mathrm{dd}, 8.1,1.9)$ & $6.90(\mathrm{dd}, 8.3,2.1)$ & $2.23-2.75^{\mathrm{b}}$ \\
$6^{\prime}$ & $6.88(\mathrm{~d}, 8.1)$ & $6.95(\mathrm{~d}, 8.3)$ & $2.23-2.75^{\mathrm{b}}$ \\
$7^{\prime}$ & $2.60(\mathrm{~m})$ & $2.70(\mathrm{~s})$ & $6.239(\mathrm{dd}, 7.8,1.7)$ \\
$8^{\prime}$ & $2.70(\mathrm{~m})$ & $2.70(\mathrm{~s})$ & $6.77(\mathrm{~d}, 7.8)$ \\
$10^{\prime}$ & $6.18(\mathrm{dd}, 7.7,1.5)$ & $5.98(\mathrm{dd}, 8.3,1.9)$ & $6.39(\mathrm{~d}, 1.7)$ \\
$11^{\prime}$ & $6.75(\mathrm{~d}, 7.7)$ & $6.17(\mathrm{~d}, 8.3)$ & $4.84(\mathrm{br} \mathrm{s})$ \\
$14^{\prime}$ & $6.36(\mathrm{~d}, 1.5)$ & $6.67(\mathrm{~d}, 1.9)$ & $5.22(\mathrm{br} \mathrm{s})^{\mathrm{c}}$ \\
$13^{\prime}-\mathrm{OH}$ & $5.35(\mathrm{~s})$ & $5.64(\mathrm{~s})$ & $5.64(\mathrm{br} \mathrm{s})^{\mathrm{c}}$ \\
$1^{\prime}-\mathrm{OH}$ & $5.98(\mathrm{~s})$ & $5.77(\mathrm{~s})$ & \\
& & & \\
$11-\mathrm{OMe}$ & $3.82(\mathrm{~s})$ & &
\end{tabular}

${ }^{*}$ Measured in $400 \mathrm{MHz}\left(\mathrm{CDCl}_{3}\right) .{ }^{* *}$ Measured in $600 \mathrm{MHz}$ (acetone-d $\left.{ }_{6}\right) .{ }^{\text {a }}$ Overlapped signals. ${ }^{\mathrm{b}}$ Complex multiplet. ${ }^{\mathrm{c}}$ Not assigned.

active substances found in the bryophytes and the evolution and differentiation of the bryophytes. At present we studied about 1000 species of the bryophytes collected in America, Africa, India, Pakistan, Nepal, Taiwan, Australia, New Zealand, Europe and Japan with respect to their chemistry, pharmacology, and application as sources of cosmetics, and medicinal or agricultural drugs. At present more than 300 new compounds have been isolated from the Hepaticae and their structures elucidated [3-5].

The chemical constituents found in the Hepaticae and those of the bryophytes have been reviewed in Progress in the Chemistry of Organic Natural Products Vol. 42 [3] and Vol. 65 [4], respectively. Heterocyclic compounds [5] and biologically active substances [7-11] isolated from liverworts have also been reviewed. Here the distribution of cyclic bis(bibenzyls) in liverworts and their structure elucidation are reviewed. In addition, some biological activity and total synthesis of the isolated cyclic bis(bibenzyls) are also discussed.

\section{Structures of cyclic bis(bibenzyls)}

Cyclic bis(bibenzyls) have been isolated from liverworts. The first isolation of this type of compounds are riccardins A (1a) and B (2) from a tiny thalloid liverwort Riccardia multifida and marchantin A (8a) from a common Marchantia polymorpha [3,12,13a]. 


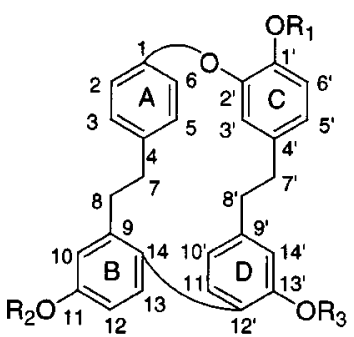

1a $R_{1}=R_{3}=H, R_{2}=M e$

1b $R_{1}=R_{3}=A C, R_{2}=M e$

1c $R_{1}=R_{2}=R_{3}=M e$

$3 \quad R_{1}=R_{2}=R_{3}=H$

$6 \quad R_{1}=M e, R_{2}=R_{3}=H$<smiles>Oc1cccc(OCc2ccc(CCc3ccc4c(c3)OCc3ccc(cc3)CCc3cc(ccc3O)O4)cc2)c1</smiles>

$10 \mathrm{R}=\mathrm{H}$

$11 \mathrm{R}=\mathrm{Me}$<smiles></smiles>

15<smiles></smiles>

2<smiles>CCOc1cc(CCc2ccc(COc3cc(CCc4ccc(OCC)c(OCC)c4)ccc3OCC)cc2)ccc1O</smiles>

$4 R_{1}=R_{2}=R_{3}=H$

$5 R_{1}=R_{3}=H, R_{2}=M e$

$7 R_{1}=M e, R_{2}=R_{3}=H$<smiles>CO[C@@H](Cc1cccc(O)c1)c1cc(O)c(O)c(OCc2ccc(CCc3cccc(O)c3)cc2)c1</smiles>

13<smiles></smiles>

17

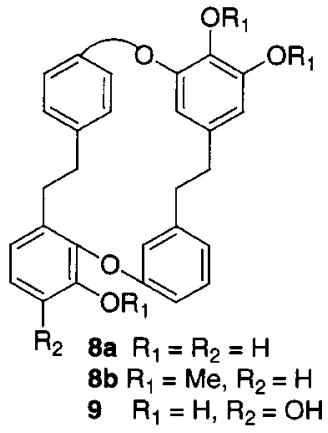<smiles>Oc1cc2ccc1CCc1ccc(cc1)OCc1cc(cc(O)c1O)C[C@H](O)c1cc(O)c(O)c(c1)O2</smiles>

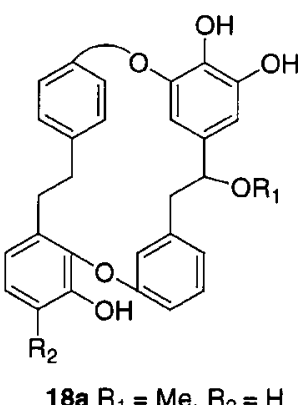

18b $R_{1}=E t, R_{2}=O H$

Chart 1. Riccardin- and marchantin-type cyclic bis(bibenzyls) isolated from the liverworts and their derivatives.

The ${ }^{1} \mathrm{H}$ NMR spectrum (Table 2) of riccardin A (1), $\mathrm{C}_{29} \mathrm{H}_{26} \mathrm{O}_{4}$ (HRMS $m / z$ 438.1831) possessed four benzylic methylenes, a methoxyl group, two phenolic hydroxyl group which was confirmed by the formation of a diacetate (1) and a trimethyl ether $(\mathbf{1} \mathbf{c})$, three meta coupled protons, one of which was heavily shielded, three sets of ortho protons and an additional two sets of ortho protons. The IR spectrum of trimethyl ether (1c) showed neither carbonyl nor hydroxyl absorption bands, indicating the additional oxygen atom of 1a to be an ether. The above spectral evidence coupled with the molecular formula displayed that 1a was a cyclic bis(bibenzyl) derivative with two phenolic hydroxyl groups, a methoxyl group, a biphenyl ether and a biphenyl linkage. The substitution of four benzene rings was deduced by the NOE and double resonance experiments of $\mathbf{1 b}$. The conclusive evidence of the stereostructure of $\mathbf{1 a}$ was obtained by X-ray crystallographic analysis of the diacetate (1b) as shown in Fig. 1. In the ${ }^{1} \mathrm{H}$ NMR spectra of $\mathbf{1 a}$ and its trimethoxy derivative (1c), H-3' appears at unusually high field (see Table 2). This is understandable as the result of the paramagnetic effect of two benzene rings $\mathrm{A}$ and $\mathrm{D}$ between which $\mathrm{H}-3^{\prime}$ is sandwiched. 


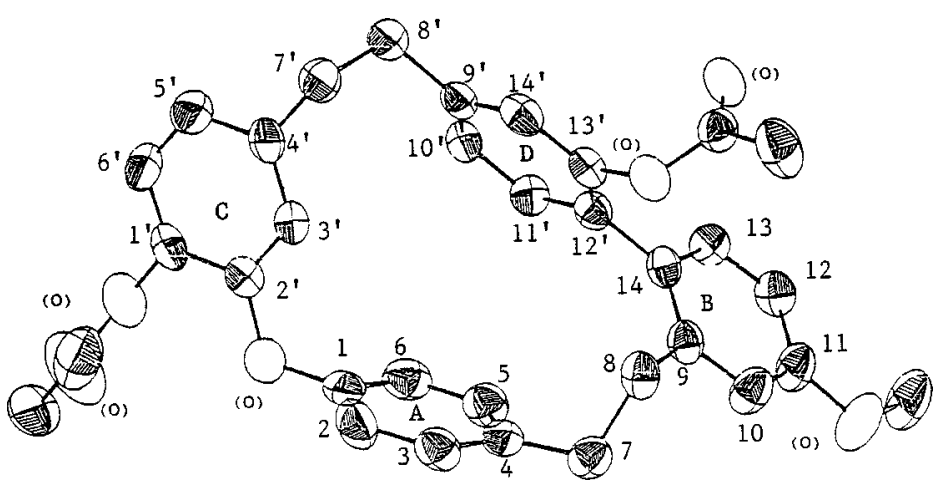

Fig. 1. ORTEP drawing of riccardin diacetate (1b).

The structure of riccardin B (2) was determined by comparison of ${ }^{1} \mathrm{H}$ and ${ }^{13} \mathrm{C}$ NMR spectra with those of riccardin A (1a) and its derivative (Table 2).

Riccardin C (3) was firstly isolated from Reboulia hemisphaerica [14]. Furthermore, it has been found in Marchantia species [15,16], New Zealand Monoclea forsteri [17], Blasia pussila [18-20], Marchantia paleacea var. diptera [21], Dumortiera hirsuta [22], Plagiochasma pterospermum [23], R. rupestre [24] and Ricciocarpos natans [25]. The structure of $\mathbf{3}$ was established by the analysis of ${ }^{1} \mathrm{H}$ and ${ }^{13} \mathrm{C} \mathrm{NMR}$ spectral data and the following chemical reaction. Methylation of riccardin $\mathrm{C}(\mathbf{3})$ gave a trimethyl ether whose spectral data were identical to the dimethyl ether (1c) of riccardin A (1a). Monoclea forsteri also produced riccardin D (4) and riccardin E (5) [17]. Furthermore, riccaridn F (6) was isolated from Blasia pussila [18-20], Marchantia paleacea var. diptera [23] and Marchantia tosana [26]. South American Marchantia chenopoda produces riccardin G (7) [27]. The structure elucidation of these compounds were carried out by extensive decoupling and NOE spectrometry on the naturally occurring compound and their permethylated products and comparison of the spectral data with those of riccardin A (1a).

Marchantia polymorpha is a common thalloid liverwort, which is widely distributed in the world and shows antihepatic, antimicrobial, diuretic and allergenic contact dermatitis [4,7-11]. The methanol extract of this liverwort contains marchantin A (8a) as a major component, along with marchantin B (9), $\mathrm{C}(\mathbf{1 0}), \mathrm{D}(\mathbf{1 2}), \mathrm{E}(\mathbf{1 3}), \mathrm{F}(\mathbf{1 4})$ and G (15) [12,15,26a,28-30a]. The ${ }^{1} \mathrm{H}$ NMR spectrum of $\mathbf{8 a}, \mathrm{C}_{28} \mathrm{H}_{24} \mathrm{O}_{5}$ $\left([\mathrm{M}]^{+} m / z 440.1617\right)$, contained signals of four benzylic methylene, three phenolic hydroxyl protons, thirteen protons on benzene rings. The structure of $\mathbf{8 a}$ was established by a combination of the chemical degradation of 8a as shown in Scheme 1, NMR spectrometry and X-ray crystallographic analysis. Treatment of $\mathbf{8 a}$ with methylene iodide in the presence of cupric oxide gave a methylene dioxide $(\mathbf{8 c})$, indicating the presence of two vicinal phenolic hydroxyls. Methylation of $\mathbf{8 a}$ gave a trimethyl ether $(\mathbf{8 b})$ which was hydrogenated to give an acyclic bis(bibenzyl) derivative (8d), followed by methylation and then by Birch reduction to afford 3-methyhoxybibenzyl (8e) and 3,4,5-trimethoxy-3'-hydroxybibenzyl (8f) which were synthesized by Wittig reaction. IR spectrum of $\mathbf{8 b}$ showed neither hydroxyl nor carbonyl absorption bands, indicating the remaining two oxygen atoms were ether oxygen. The direct Birch reduction of $\mathbf{8 b}$ yielded 4-hydroxy-3-methoxybibenzyl $(\mathbf{8 g})$ and 3-hydroxy-3,4'-dimethoxybibenbzyl $(\mathbf{8 h})$ which were also synthesized by Wittig reaction. On the basis of the above chemical and ${ }^{1} \mathrm{H}$ and ${ }^{13} \mathrm{C}$ NMR spectral evidence (Tables 2 and 8 ) of $\mathbf{8 a}$ and $\mathbf{8 b}$, the structure of $\mathbf{8 a}$ was suggested to be a cyclic bis(bibenzyl) with two ether linkage between $\mathrm{C}-1$ and $\mathrm{C}-2^{\prime}$ and between $\mathrm{C}-14$ and C-11' , possessing three phenolic hydroxyl group at $\mathrm{C}-13, \mathrm{C}-1^{\prime}$ and $\mathrm{C}-6^{\prime}$. In order to confirm the stereochemistry, recrystallization of marchantin itself and its derivatives were carried out. Marchantin series are very viscous 


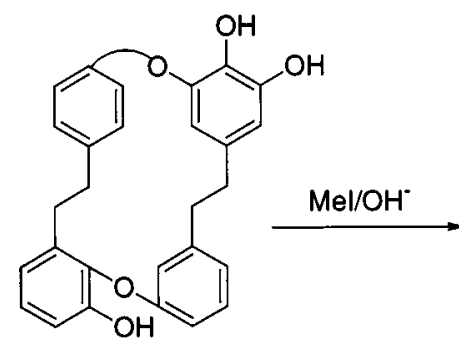

$8 \mathbf{a}$ $\mathrm{CH}_{2} \mathrm{I}_{2} / \mathrm{CuO} / \mathrm{DMSO}$<smiles>Oc1cccc2c1Oc1cccc(c1)CCc1ccc(cc1)COc1cc(CCc3ccc4c(c3)OCO4)ccc1OCO2</smiles>

$8 c$<smiles>COc1cccc(CCc2ccc(CCc3cccc(OC)c3OCc3ccc(O)c(OC)c3)cc2)c1</smiles>

8b $\mathrm{Na} / \mathrm{liq} . \mathrm{NH}_{3}$<smiles>COc1cc(CCc2cccc(OC)c2OCc2cccc(CCc3ccccc3)c2)cc(O)c1OC</smiles>

8d

1) $\mathrm{Mel} / \mathrm{OH}^{-}$ 2) $\mathrm{Na}$ /liq. $\mathrm{NH}_{3}$<smiles>COc1cccc(CCc2ccc(OCCCCCc3cccc(O)c3)cc2)c1</smiles>

$8 \mathbf{g}$

8h<smiles>COc1cccc(CCc2ccccc2)c1</smiles>

$8 e$<smiles>COc1cc(CCc2cccc(O)c2)cc(OC)c1OC</smiles>

8f

Scheme 1. Chemical reactions of marchantin A (8a).

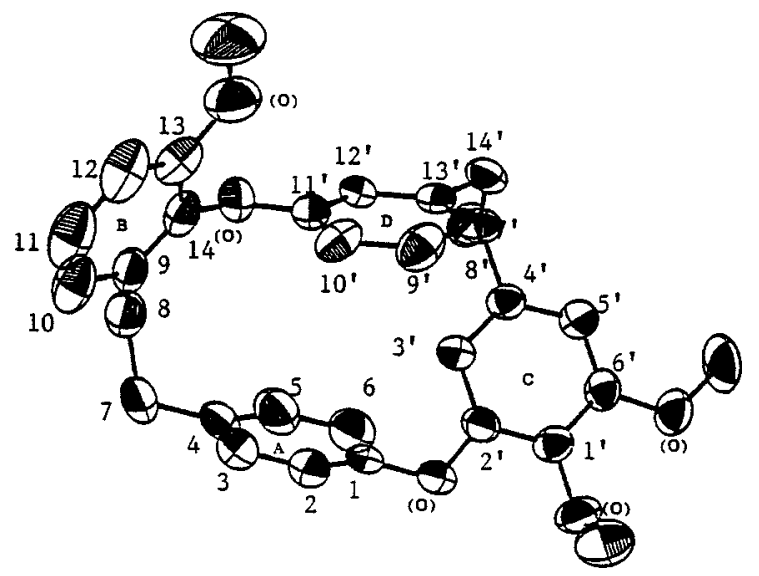

Fig. 2. ORTEP drawing of marchantin A trimethyl ether (8b).

gum, however, only the trimethyl ether $(\mathbf{8 b})$, which was chromatographed on silica gel- $\mathrm{MgSO}_{4}(1: 1)$ furnished crystals suitable for X-ray crystallographic analysis. The ORTEP drawing has been shown in Fig. 2.

In the ${ }^{1} \mathrm{H}$ NMR spectra of $\mathbf{8 a}$ and $\mathbf{8 b}$, a strongly shielded one proton doublet at $\delta 5.13(1 \mathrm{H})$ for $\mathbf{8 a}$ and 5.30 for $\mathbf{8 b}$ has been assigned to an inner proton $\left(\mathrm{H}-3^{\prime}\right)$ in benzene ring A which lies over the plane of benzene ring. Marchantin A (8a) has also been isolated from Marchantia paleacea var. diptera [26a,26c], 
Table 3

${ }^{1}$ H NMR spectral data for marchantin A (8a), its trimethyl ether $(\mathbf{8 b})$ and marchantin B $(\mathbf{9})^{*}$

\begin{tabular}{llll}
\hline & \multicolumn{1}{c}{$(\mathbf{8 a})$} & \multicolumn{1}{c}{$(\mathbf{8 b})$} & \multicolumn{1}{c}{$(\mathbf{9})$} \\
\hline 2,6 & $6.58(\mathrm{~d}, 8.5)$ & $6.56(\mathrm{~d}, 8.5)$ & $6.58(\mathrm{~d}, 8.5)$ \\
3,5 & $6.93(\mathrm{~d}, 8.5)$ & $6.90(\mathrm{~d}, 8.5)$ & $6.93(\mathrm{~d}, 8.5)$ \\
7,8 & $2.96-3.01(\mathrm{~m})$ & $2.99-3.04(\mathrm{~m})$ & $2.91-2.99(\mathrm{~m})$ \\
10 & $7.02(\mathrm{dd}, 7.8,1.5)$ & $7.06(\mathrm{dd}, 8.1,1.5)$ & $6.92(\mathrm{~d}, 8.5)$ \\
11 & $7.15(\mathrm{t}, 7.8)$ & $7.17(\mathrm{t}, 8.1)$ & $6.85(\mathrm{~d}, 8.5)$ \\
12 & $6.87(\mathrm{dd}, 7.8,1.5)$ & $6.80(\mathrm{dd}, 8.1,1.5)$ & $5.13(\mathrm{~d}, 1.8)$ \\
$3^{\prime}$ & $5.13(\mathrm{~d}, 2.0)$ & $5.30(\mathrm{~d}, 1.7)$ & $6.47(\mathrm{~d}, 1.8)$ \\
$5^{\prime}$ & $6.47(\mathrm{~d}, 2.0)$ & $6.42(\mathrm{~d}, 1.7)$ & \\
$6^{\prime}$ & & & $2.74-2.82(\mathrm{~m})$ \\
$7,8^{\prime}$ & $2.72-2.78(\mathrm{~m})$ & $2.73-2.88(\mathrm{~m})$ & $6.569(\mathrm{dd}, 2.3,1.5)$ \\
$10^{\prime}$ & $6.85(\mathrm{t}, 2.0)$ & $6.51(\mathrm{t}, 1.8)$ & $6.56(\mathrm{ddd}, 7.8 .2 .3,1.0)$ \\
$12^{\prime}$ & $6.55(\mathrm{dd}, 7.8,2.1)$ & $6.47(\mathrm{ddd}, 8.1,2.4,1.0)$ & $6.99(\mathrm{t}, 7.8)$ \\
$13^{\prime}$ & $6.98(\mathrm{t}, 7.8)$ & $6.93(\mathrm{t}, 8.1)$ & $6.41(\mathrm{ddd}, 7.8,1.5,1.0)$ \\
$14^{\prime}$ & $6.41(\mathrm{br} \mathrm{d}, 7.8)$ & $6.34(\mathrm{brd}, 8.1)$ & \\
$13-\mathrm{OMe}$ & & $3.64(\mathrm{~s})$ & \\
$1^{\prime}-\mathrm{OMe}$ & & $3.89(\mathrm{~s})$ & \\
$6^{\prime}-\mathrm{OMe}$ & $3.87(\mathrm{~s})$ & \\
\hline
\end{tabular}

${ }^{*}$ Measured in $400 \mathrm{MHz}\left(\mathrm{CDCl}_{3}\right)$.

Table 4

${ }^{1} \mathrm{H}$ NMR spectral data for marchantin C (10), H (16) and marchantin J trimethyl ether (18b)*

\begin{tabular}{llll}
\hline & \multicolumn{1}{c}{$(\mathbf{1 0})$} & \multicolumn{1}{c}{$(\mathbf{1 6})$} & \multicolumn{1}{c}{$\mathrm{MJ}(\mathrm{OMe})_{3}$ of $(\mathbf{1 8 b})$} \\
\hline 2,6 & $6.60(\mathrm{~d}, 8.5)$ & $6.59(\mathrm{~d}, 8.3)$ & $6.52(\mathrm{br} \mathrm{d}, 7.7)$ \\
3,5 & $6.94(\mathrm{~d}, 8.5)$ & $6.93(\mathrm{~d}, 8.3)$ & $6.89(\mathrm{br} \mathrm{d}, 7.7)$ \\
7,8 & $2.97-3.03(\mathrm{~m})$ & $2.91-2.99(\mathrm{~m})$ & $2.93-3.17(\mathrm{~m})$ \\
10 & $7.02(\mathrm{dd}, 7.8,1.6)$ & $6.92(\mathrm{~d}, 8.3)$ & $7.07(\mathrm{dd}, 7.8,1.0)$ \\
11 & $7.15(\mathrm{t}, 7.8)$ & $6.87(\mathrm{~d}, 8.3)$ & $7.21(\mathrm{t}, 7.8)$ \\
12 & $6.87(\mathrm{dd}, 7.8,1.6)$ & & $6.82(\mathrm{br} \mathrm{d}, 1.5)$ \\
$3^{\prime}$ & $5.52(\mathrm{~d}, 2.0)$ & $5.53(\mathrm{~d}, 2.0)$ & $5.02(\mathrm{~d}, 2.0)$ \\
$5^{\prime}$ & $6.74(\mathrm{dd}, 8.1,2.0)$ & $6.73(\mathrm{dd}, 8.7,2.0)$ & $6.70(\mathrm{~d}, 1.5)$ \\
$6^{\prime}$ & $6.88(\mathrm{~d}, 8.1)$ & $6.85(\mathrm{~d}, 8.7)$ & \\
$7,8^{\prime}$ & $2.75-2.86(\mathrm{~m})$ & $2.75-2.87(\mathrm{~m})$ & $4.20(\mathrm{dd}, 11,3.9)$ \\
& & & $3.15(\mathrm{~m})$ \\
$10^{\prime}$ & & & $2.61(\mathrm{~m})$ \\
$12^{\prime}$ & $6.62(\mathrm{dd}, 2.5,1.5)$ & $6.61(\mathrm{dd}, 2.4,1.4)$ & $6.72(\mathrm{t}, 1.5)$ \\
$13^{\prime}$ & $6.54(\mathrm{ddd}, 7.8,2.5,0.7)$ & $6.54(\mathrm{ddd}, 7.8 .2 .4,0.7)$ & $6.34(\mathrm{ddd}, 8.0,2.0,1.0)$ \\
$14^{\prime}$ & $6.98(\mathrm{t}, 7.8)$ & $6.97(\mathrm{t}, 7.8)$ & $6.81(\mathrm{t}, 8.0)$ \\
$13-\mathrm{OMe}$ & $6.38(\mathrm{ddd}, 7.8,1.5,0.7)$ & $6.37(\mathrm{br} \mathrm{d}, 7.8)$ & $6.02(\mathrm{br} \mathrm{d}, 8.0)$ \\
$1^{\prime}-\mathrm{OMe}$ & & & $3.66(\mathrm{~s})$ \\
$6^{\prime}-\mathrm{OMe}$ & & & $3.92(\mathrm{~s})$ \\
$7^{\prime}-\mathrm{OEt}$ & & & $3.92(\mathrm{~s})$ \\
& & & $3.45(\mathrm{~m}, \mathrm{CH})$ \\
\hline
\end{tabular}

${ }^{*}$ Measured in $400 \mathrm{MHz}\left(\mathrm{CDCl}_{3}\right)$. 


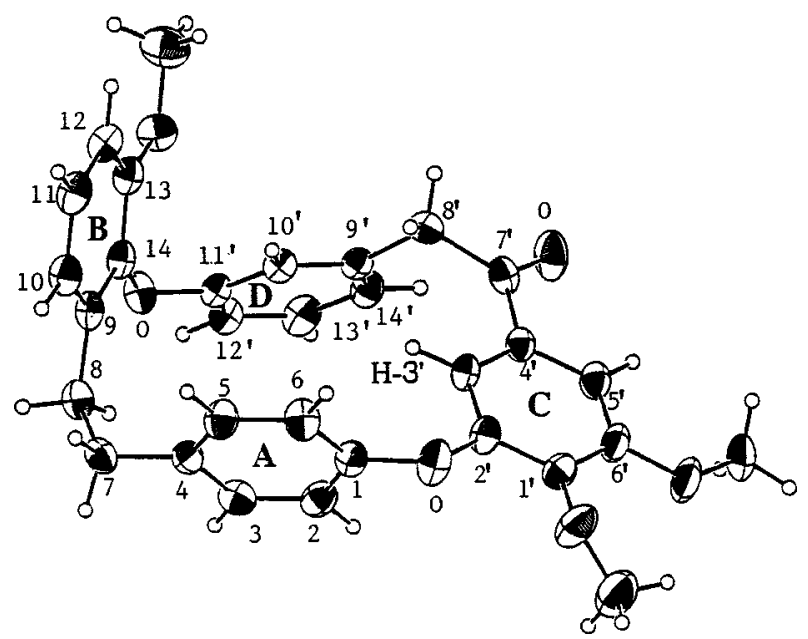

Fig. 3. ORTEP drawing of marchantin G (15) trimethyl ether.

M. plicata [35] and M. tosana [26a], which belong to the Marchantiaceae, Plagiochasma appendiculatum to the Aytoniaceae [26b] and Wiesnerella denudata to the Conocepharaceae [36].

The structures of the other marchantins B, D-G (9-15) were determined by comparison of their spectral data (Tables 2-4) with those of marchantin A (8) and chemical correlation. Recently, the stereochemistry of marchantin G (15) was confirmed by its X-ray crystallographic analysis [30b] as shown in Fig. 3. The yield of marchantin A (8a) depends on the Marchantia species. For example $120 \mathrm{~g}$ of pure marchantin A has been obtained from $2 \mathrm{~kg}$ of the dried M. polymorpha.

The similar marchantin series, marchantin $\mathrm{H}$ (16) and marchantin I (17) were obtained from Plagiochasma rupestre and Riccardia multifida, respectively [31]. Their ${ }^{1} \mathrm{H}$ and ${ }^{13} \mathrm{C}$ NMR spectral data are shown in Tables 4 and 8. Marchantin A (8a) has been biosynthesized from lunularic acid (66a) by shikimic-malonate pathway [32a,32b].

Since marchantins A-G have been isolated from Marchantia species, marchantin C dimethyl ether (11) [34], marchantins $\mathrm{J}-\mathrm{N}$ (18-21), isomarchantin C (22) and isoriccardin C (23) have been isolated from the different Marchantia species [15,16,25,26a,35-38], Dumortiera hirsuta [21], Bryopteris filicina [39], Mylia nuda [40,41], Wiesnerella denudata [36], Monoclea forsteri [42], Plagiochila sciophila [43], Reboulia hemisphaerica [44] and Plagiochasma rupestre [45].

The spectral data of the trimethyl ether (18b) of marchantin J (18a) possessed an ethoxyl group resembled those of marchantin E (13), except for replacement of the methoxyl by an ethoxyl group, indicating that marchantin $\mathrm{J}$ was marchantin A mono ethyl ether. This was confirmed by ${ }^{1} \mathrm{H}$ and ${ }^{13} \mathrm{C}$ NMR spectrometry (Tables 4 and 8) including NOE difference spectra. This is the first record of an ethoxylated compound from liverworts.

The structure of isomarchantin C (22) isolated from the Indian Marchantia polymorpha and M. palmata [15] was characterized by analysis of the ${ }^{1} \mathrm{H}$ and ${ }^{13} \mathrm{C}$ MR spectra. The same compound was isolated Dumortiera hirsuta and its structure was confirmed by X-ray crystallographic analysis as shown in Fig. 4 [22]. R. hemisphaerica and Mannia subpilosa produce marchantia quinone (26) $[34,44]$. Marchantin O (24), the monomethyl ether of marchantin C (10), and marchantin P (25) were obtained from $R$. hemisphaerica [44,46,47] and South American Marchantia chenopoda, respectively [37]. Their structures have been elucidated by analysis of the spectral data including difference NOE of the permethylated and the peracetylated derivatives. 
<smiles>Oc1cccc(CCc2cc3c(O)c(c2)Oc2cc(O)cc(c2)Oc2c(O)cccc2C[C@H](O)c2ccc(cc2)CO3)c1</smiles><smiles>Oc1cc2ccc1CCc1ccc(c(O)c1)COc1cc(ccc1O)CCc1ccc(cc1)CC2</smiles>

23<smiles>COc1ccc(O)c(CCc2ccc(CCc3ccc(O)c(OCc4ccccc4)c3)cc2)c1</smiles>

20<smiles>CCOc1ccc(CCc2cccc(OCc3ccc(CCc4ccccc4)cc3)c2)cc1OCC</smiles>

$24 R_{1}=H, R_{2}=M e$ $25 R_{1}=M e, R_{2}=H$<smiles>COC1=CC(=O)C2=C(CCc3ccc(cc3)COC3=CC(=CC=C2)CCc2ccc(O)c(c2)OC3)C1=O</smiles>

21<smiles></smiles>

26<smiles>Oc1ccc2cc1CCc1ccc(c(O)c1)OCc1ccc(cc1)CCc1ccc(cc1)OC2</smiles>

22<smiles>[R7]c1cc(O)cc(/C=C/c2cc(O)ccc2Oc2cccc(C([R2])Cc3ccc(COc4ccccc4)cc3)c2)c1</smiles>

$27 R_{1}=R_{2}=H$

$28 R_{1}=\mathrm{OH}, \mathrm{R}_{2}=\mathrm{H}$

$29 R_{1}=H, R_{2}=O H$<smiles>O=C(O)c1ccc(CCc2cccc(Oc3ccc(OCc4ccccc4)cc3)c2)cc1CCc1ccc(O)c([18OH])c1</smiles>

$30 R_{1}=M e, R_{2}=R_{3}=H$ $31 R_{1}=R_{2}=R_{3}=H$

$32 \mathrm{R}_{1}=\mathrm{R}_{2}=\mathrm{H}, \mathrm{R}_{3}=\mathrm{OH}$<smiles>COc1cc(C=[Pb]P)c(O)c(CCc2ccc(COc3cc(CCc4cc(O)cc(O)c4O)ccc3-c3ccc(O)cc3)cc2)c1</smiles>

$33 \mathrm{R}=\mathrm{OH}$
$34 \mathrm{R}=\mathrm{H}$

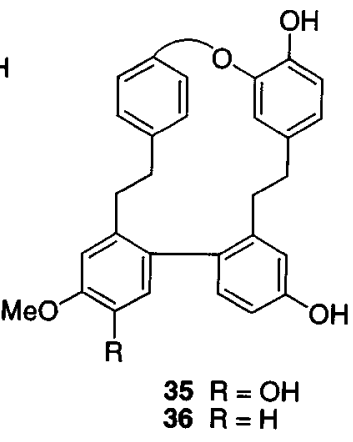

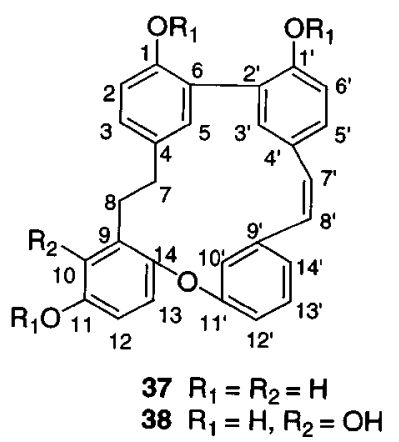

Chart 2. Marchantin-, isomarchantin-, isoriccardin-, neomarchantin-, plagiochin- and isoplagiochin-type cyclic bis(bibenzyls) isolated from the liverworts.

Three novel macrocyclic bis(bibenzyls) named ptychantols A-C (27-29), which possess a transstilbene moiety were isolated from the stem-leafy liverwort Ptychantus striatus [48]. Compound 27 contained two benzylic methylenes, trans ethylenic protons at $\delta 6.49$ and $6.97\left(J=16.5 \mathrm{~Hz}, \mathrm{H}-8^{\prime}\right.$ and $\mathrm{H}-7^{\prime}$, respectively) (Table 5), two phenolic protons, and 14 aromatic protons on four benzene rings. Methylation of $\mathbf{2 7}$ gave a dimethyl ether, whose IR spectrum indicated neither hydroxyl nor carbonyl absorption bands, indicating the presence two ether oxygen in 27. Hydrogenation of 27 gave a dihydro derivative, showing that 27 contained one olefinic group. The substitution pattern on benzene rings was suggested by analysis of ${ }^{1} \mathrm{H}$ and ${ }^{13} \mathrm{C}$ NMR spectral data (Tables 5 and 9), HMBC and NOESY spectra. The conclusive evidence for the structure of $\mathbf{2 7}$ was established by X-ray crystallographic analysis. The ORTEP drawing has been shown in Fig. 5. The ${ }^{1} \mathrm{H}$ and ${ }^{13} \mathrm{C}$ NMR data of ptychantol $\mathrm{C}(\mathbf{2 9})$ are indicated in Tables 8 and 9. Compound $\mathbf{2 9}$ was isolated as optically active form with a specific rotation $\left[[\alpha]_{\mathrm{D}}-14.8^{\circ}(c 0.66, \mathrm{MeOH})\right]$ and Cotton effect $[289 \mathrm{~nm}(\Delta \varepsilon+10.64), 270 \mathrm{~nm}(\Delta \varepsilon-3.0), 233 \mathrm{~nm}$ $(\Delta \varepsilon+21.2)$ and $235 \mathrm{~nm}(\Delta \varepsilon-30.8)]$ in $\mathrm{CD}$ spectrum. However, the absolute configuration of 29 remains to be identified. 


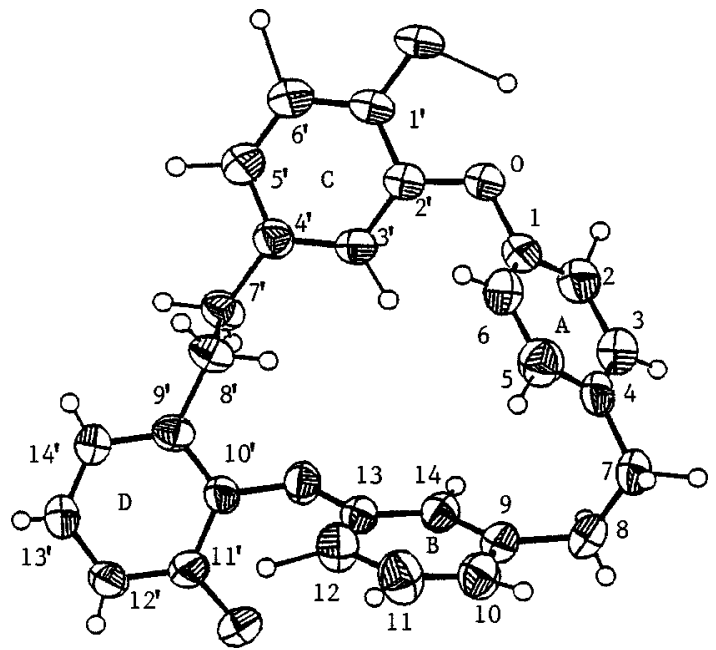

Fig. 4. ORTEP drawing of isomarchantin C (22).

Table 5

${ }^{1}$ H NMR spectral data for ptychantol A (27), C (29) and plagiochin A (33)

\begin{tabular}{llll}
\hline & \multicolumn{1}{c}{$(\mathbf{2 7})^{*}$} & \multicolumn{1}{c}{$(\mathbf{2 9})^{*}$} & \multicolumn{1}{c}{$(\mathbf{3 3})^{* *}$} \\
\hline 2 & $6.89(\mathrm{~d}, 8.2)$ & $6.96(\mathrm{dd}, 8.5,2.5)$ & $6.67(\mathrm{dd}, 8.3,3.2)$ \\
3 & $7.17(\mathrm{~d}, 8.2)$ & $7.27(\mathrm{dd}, 8.2,2.2)$ & $6.86(\mathrm{dd}, 8.3)$ \\
5 & $7.17(\mathrm{~d}, 8.2)$ & $7.06(\mathrm{dd}, 8.5,2.2)$ & $6.90(\mathrm{dd}, 8.3,2.2)$ \\
6 & $6.89(\mathrm{~d}, 8.2)$ & $6.79(\mathrm{dd}, 8.5,2.5)$ & $6.71(\mathrm{dd}, 8.3,2.2)$ \\
7 & $3.10(\mathrm{~m})$ & $3.13(\mathrm{dd}, 12.9,8.8)$ & $2.75-3.09(\mathrm{~m})$ \\
& & $4.40(\mathrm{dd}, 12.9,4.7)$ & $2.75-3.09(\mathrm{~m})$ \\
8 & $3.10(\mathrm{~m})$ & $5.08(\mathrm{dd}, 8.8,4.7)$ & $7.09(\mathrm{~s})$ \\
10 & $6.99(\mathrm{ddd}, 8.0,1.9,1.9)$ & $7.17(\mathrm{ddd}, 8.0,2.2,2.2)$ & $6.70(\mathrm{~s})$ \\
11 & $7.06(\mathrm{dd}, 8.0,8.0)$ & $7.14(\mathrm{dd}, 8.0,8.0)$ & $4.84(\mathrm{~d}, 2.0)$ \\
12 & $6.08(\mathrm{ddd}, 8.0,1.9,1.9)$ & $6.27(\mathrm{ddd}, 8.0,2.2,2.2)$ & $6.37(\mathrm{~d}, 2.0)$ \\
13 & & & \\
14 & $6.63(\mathrm{dd}, 1.9,1.9)$ & $6.78(\mathrm{dd}, 2.2,2.2)$ & $2.70-3.09(\mathrm{~m})$ \\
$3^{\prime}$ & $6.41(\mathrm{~d}, 1.9)$ & $6.43(\mathrm{~d}, 2.2)$ & $2.19(\mathrm{~m})$ \\
$5^{\prime}$ & $6.82(\mathrm{dd}, 8.0,1.9)$ & $6.82(\mathrm{dd}, 8.2,2.2)$ & $6.85(\mathrm{~d}, 8.3)$ \\
$6^{\prime}$ & $6.86(\mathrm{~d}, 8.0)$ & $6.86(\mathrm{~d}, 8.2)$ & $6.60(\mathrm{dd}, 8.2,2.4)$ \\
$7^{\prime}$ & $6.97(\mathrm{~d}, 16.5)$ & $6.97(\mathrm{~d}, 16.5)$ & $6.53(\mathrm{~d}, 2.4)$ \\
$8^{\prime}$ & $6.49(\mathrm{~d}, 16.5)$ & $6.48(\mathrm{~d}, 16.5)$ & $3.99(\mathrm{~s})$ \\
$11^{\prime}$ & $6.91(\mathrm{~d}, 8.5)$ & $6.91(\mathrm{~d}, 8.5)$ & $6.80(\mathrm{dd}, 8.5,2.7)$ \\
$12^{\prime}$ & $6.81(\mathrm{~d}, 8.5,3.0)$ & $7.26(\mathrm{~d}, 2.7)$ & $8.48(\mathrm{br} \mathrm{s})$ \\
$14^{\prime}$ & $7.27(\mathrm{~d}, 3.0)$ & & \\
$13^{\prime}-\mathrm{OH}$ & $8.40(\mathrm{br} \mathrm{s})$ & & \\
$11-\mathrm{OMe}$ & & & \\
\hline
\end{tabular}

${ }^{*}$ Measured in $600 \mathrm{MHz}$ (acetone- $\mathrm{d}_{6}$ ).

${ }^{* *}$ Measured in $400 \mathrm{MHz}\left(\mathrm{CDCl}_{3}+\mathrm{MeOH}-\mathrm{d}_{4}\right)$. 


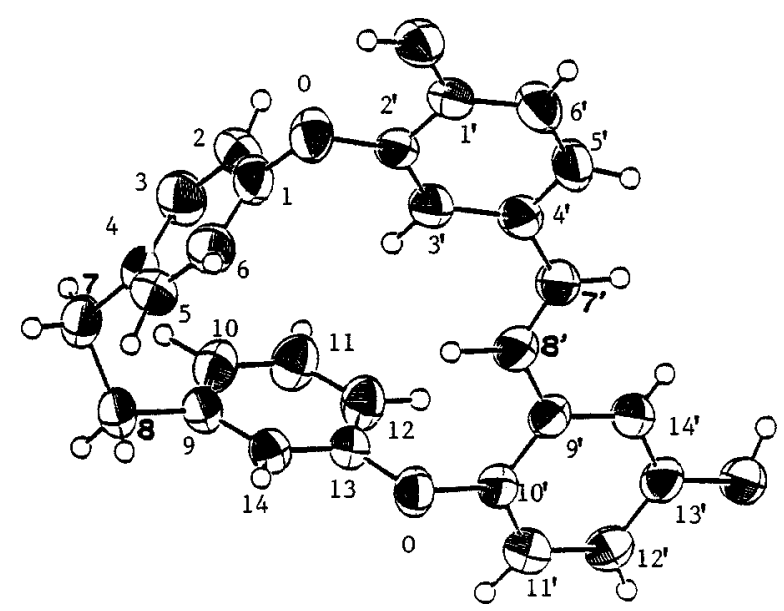

Fig. 5. ORTEP drawing of ptychantol A (27).

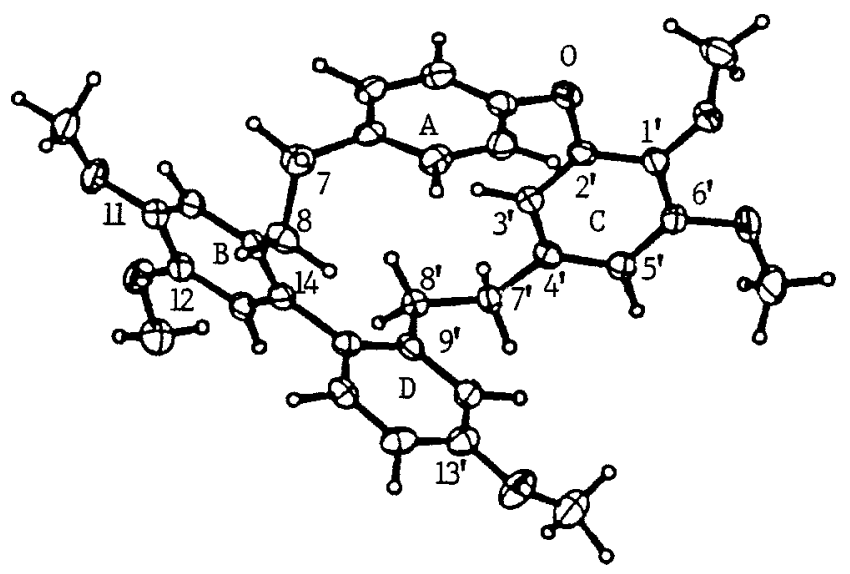

Fig. 6. ORTEP drawing of plagiochin A (33) trimethyl ether.

Mannia fragrans elaborates pakyonol (30) [49]. The New Zealand liverwort Schitochila glaucescens elaborates neomarchantin A (31) and B (32) [50]. The former compound was also isolated from the German Preissia quadrata [51]. Plagiochila sciophila produces not only marchantin C (10) and an acyclic bis(bibenzyl), perrottetin $\mathrm{E}$ (59), the latter member of the perrottetin class, which contains single $o$, pether linkage between two bis(bibenzyl) groups, but also four unique cyclic bis(bibenzyls), plagiochin A-D (33-36) which possess two ortho biphenyl linkage between the two benzyl groups [43]. The stereochemistry of compound (33) was established by chemical reactions (methylation and acetylation). The ${ }^{1} \mathrm{H}$ and ${ }^{13} \mathrm{C}$ NMR spectrometry (Tables 5 and 9) and NOE studies on its tetramethyl ether as well as by an X-ray crystallographic analysis (see Fig. 6) of the latter. This showed that ring $\mathrm{A}$ is perpendicular to ring $\mathrm{C}$ and parallel with ring $\mathrm{D}$. The proton at $\mathrm{C}-3^{\prime}$ is strongly shielded by both rings $\mathrm{A}$ and $\mathrm{D}$, causing a high field shift to $\delta 4.84$ in the tetramethyl ether of 33. This phenomenon has been also encountered in the series of marchantins and riccardins described earlier.

Further fractionation of the methanol extract of P. fruticosa resulted in the isolation of isoplagiochin A-D (37-40) [18,52-55]. The number of the phenolic hydroxyl group of $\mathbf{3 7}$ was three, determined by acetylation and methylation to give a triacetate and trimethyl ether. The ${ }^{1} \mathrm{H}$ and ${ }^{13} \mathrm{C}$ NMR spectra of 
Table 6

${ }^{1} \mathrm{H}$ NMR spectral data for isoplagiochin A (37), C (39) and D (40)

\begin{tabular}{llll}
\hline & \multicolumn{1}{c}{$(\mathbf{3 7})^{*}$} & \multicolumn{1}{c}{$(\mathbf{3 9})^{*}$} & \multicolumn{1}{c}{$(\mathbf{4 0})^{* *}$} \\
\hline 2 & $6.75(\mathrm{~d}, 8.1)$ & $6.78(\mathrm{~d}, 8.1)$ & $6.79(\mathrm{~d}, 7.8)$ \\
3 & $7.02(\mathrm{dd}, 8.1,2.2)$ & $6.98(\mathrm{dd}, 8.1,2.2)$ & $7.00(\mathrm{dd}, 7.8,2.4)$ \\
5 & $6.50(\mathrm{br} \mathrm{s})$ & $6.60(\mathrm{~d}, 2.2)$ & $6.39(\mathrm{~d}, 2.4)$ \\
7 & $2.64(\mathrm{~m})$ & $2.67(\mathrm{~m})$ & $2.70(\mathrm{~m})$ \\
8 & $2.62(\mathrm{~m})$ & $2.67(\mathrm{~m})$ & $2.70(\mathrm{~m})$ \\
10 & $6.83(\mathrm{~d}, 3.0)$ & $6.85(\mathrm{~d}, 2.4)$ & $6.84(\mathrm{~d}, 2.4)$ \\
12 & $6.71(\mathrm{dd}, 8.6,2.9)$ & $6.77(\mathrm{dd}, 8.3,2.4)$ & $6.72(\mathrm{dd}, 8.1,2.4)$ \\
13 & $6.93(\mathrm{~d}, 8.5)$ & $7.12(\mathrm{~d}, 8.3)$ & $6.99(\mathrm{~d}, 8.1)$ \\
$3^{\prime}$ & $7.31(\mathrm{~d})$ & $7.28(\mathrm{~d}, 2.2)$ & $6.51(\mathrm{~d}, 2.2)$ \\
$5^{\prime}$ & $7.15(\mathrm{dd}, 8.3,2.2)$ & $7.15(\mathrm{dd}, 8.3,2.2)$ & $7.13(\mathrm{dd}, 7.8,2.4)$ \\
$6^{\prime}$ & $6.87(\mathrm{~d}, 8.2)$ & $6.90(\mathrm{~d}, 8.3)$ & $6.89(\mathrm{~d}, 8.1)$ \\
$7^{\prime}$ & $6.58(\mathrm{~d}, 12.0)$ & $6.55(\mathrm{~d}, 11.7)$ & $2.70-3.10(\mathrm{~m})$ \\
$8^{\prime}$ & $6.63(\mathrm{~d}, 12.0)$ & $6.465(\mathrm{~d}, 11.7)$ & $2.70-3.10(\mathrm{~m})$ \\
$10^{\prime}$ & $7.30(\mathrm{br} \mathrm{s})$ & $6.88(\mathrm{dd}, 8.1,2.2)$ & $6.74(\mathrm{dd}, 7.8,2.2)$ \\
$11^{\prime}$ & & $7.17(\mathrm{~d}, 8.1)$ & $7.07(\mathrm{~d}, 7.8)$ \\
$12^{\prime}$ & $6.33(\mathrm{~d}, 8.3,2.6)$ & & \\
$13^{\prime}$ & $7.13(\mathrm{t}, 8.0)$ & & $6.73(\mathrm{~d}, 2.2)$ \\
$14^{\prime}$ & $6.70(\mathrm{br} \mathrm{d}, 7.5)$ & $6.89(\mathrm{~d}, 2.2)$ & \\
\hline
\end{tabular}

${ }^{*}$ Measured in $400 \mathrm{MHz}\left(\mathrm{CDCl}_{3}+\right.$ methanol- $\left.\mathrm{d}_{4}\right)$.

${ }^{* *}$ Measured in $600 \mathrm{MHz}$ (acetone- $\mathrm{d}_{6}$ ).

${ }^{a}$ Overlapped signal.

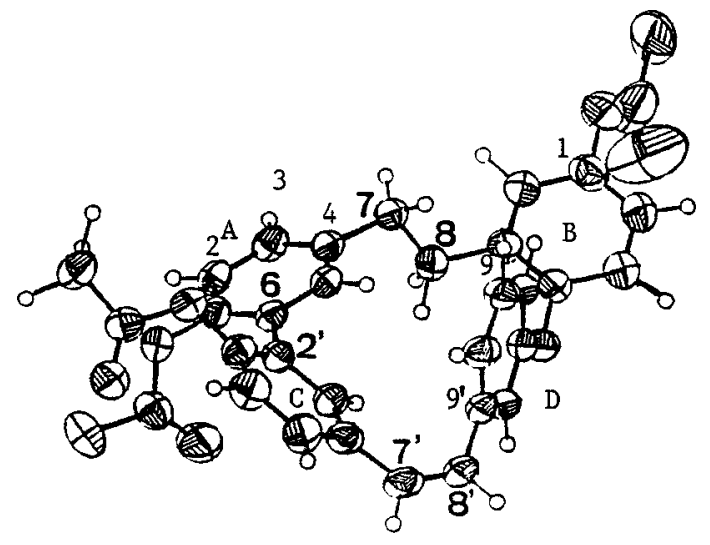

Fig. 7. ORTEP drawing of isoplagiochin A (37) trimethyl ether.

37 (Tables 6 and 9) showed the presence of two benzylic methylenes and cis-olefinic protons $(\delta 6.59$, 6.63 (each $1 \mathrm{H}, \mathrm{d}, J=9 \mathrm{~Hz}, \mathrm{H}-7$ and $\mathrm{H}-8$ ). The hydrogenation of 37 gave a dihydro derivative. The stereostructure of $\mathbf{3 7}$ was finally established by a combination of COSY, HMQC and HMBC of $\mathbf{3 7}$ and NOE difference spectra of a trimethyl and triacetate of $\mathbf{3 7}$ and X-ray crystallographic analysis as shown in Fig. 7. The ${ }^{1} \mathrm{H}$ and ${ }^{13} \mathrm{C}$ NMR spectra (Tables 6 and 9) of 39 resembled those of isoplagiochin A (37) except for the signal patterns of D-ring, indicating that $\mathbf{3 9}$ possessed the same skeleton as that of $\mathbf{3 7}$. The molecular formula of $\mathbf{3 9}$ was identical to that of $\mathbf{3 7}$, suggesting that the former compound contained an additional phenolic hydroxyl group at D-ring in place of an ether oxygen in compound 37. 
<smiles>Oc1cc2ccc1CCc1ccc(O)c(c1)-c1cc(ccc1O)C=Cc1ccc(c(O)c1)-c1cc(ccc1O)CC2</smiles>

39

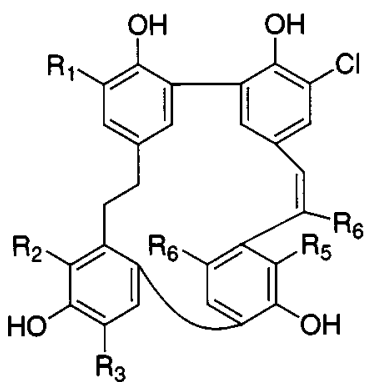

$45 R_{1}=R_{2}=R_{3}=R_{4}=R_{5}=R_{6}=H$

$46 R_{1}=R_{2}=R_{3}=R_{5}=R_{6}=H, R_{4}=\mathrm{Cl}$

$47 R_{1}=R_{2}=R_{5}=R_{6}=H, R_{3}=R_{4}=C l$

$48 R_{1}=R_{2}=R_{3}=R_{6}=H, R_{4}=R_{5}=\mathrm{Cl}$

$49 R_{1}=R_{2}=R_{6}=H, R_{3}=R_{4}=R_{5}=C l$

$50 R_{1}=R_{3}=R_{5}=H, R_{2}=R_{4}=R_{6}=C l$

$51 R_{3}=R_{6}=H, R_{1}=R_{2}=R_{4}=R_{5}=C l$

$52 R_{1}=R_{3}=H, R_{2}=R_{4}=R_{5}=R_{6}=C l$

$53 R_{1}=R_{3}=R_{4}=R_{5}=R_{6}=C l, R_{2}=H$<smiles>Oc1cccc(CCc2ccc(O)c(-c3cccc(O)c3)c2)c1</smiles>

40<smiles>Oc1ccc(CCc2cc3cc(c2)-c2cc(ccc2O)CCc2ccc(cc2O)-c2cc(Cl)c(O)cc2CC3)cc1Cl</smiles>

54

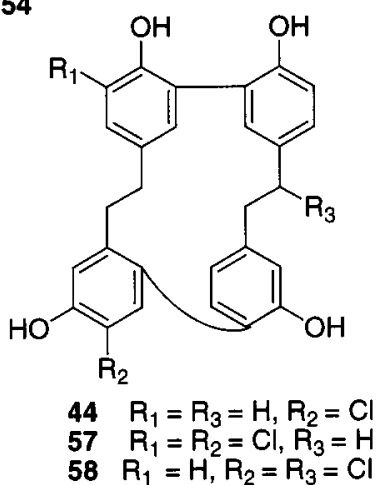<smiles>Oc1ccc(CCc2ccc3c4ccc(O)c(c4)c4cccc(O)c4ccc4cccc(c4)oc3c2)cc1O</smiles><smiles>[R]c1c(O)ccc2c1CCc1ccc(O)c(c1)-c1cc(ccc1O)CCc1ccc(cc1)CC2</smiles>

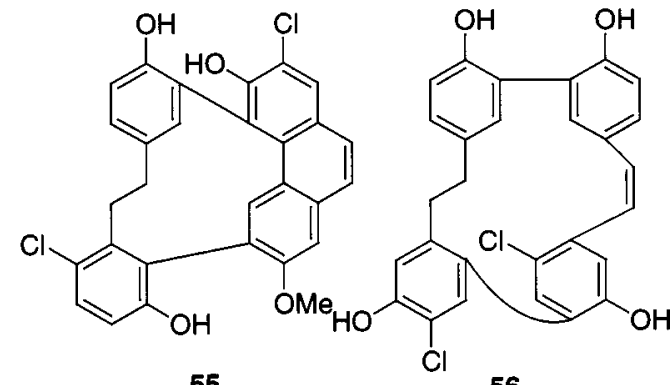

55<smiles>Oc1cccc(CCc2ccc(CCc3cccc(O)c3)c(OCc3ccc(O)c(O)c3)c2)c1</smiles>

59

Chart 3. Isoplagiochin-type cyclic bis(bibenzyls), bibenzyl-phenanthrene and acyclic bis(bibenzyl) isolated from the liverworts.

This assumption was confirmed by the formation of a tetraacetate from 39. The location of the hydroxyl group at $\mathrm{C}-13^{\prime}$ and the whole structure were determined by careful analysis of the 2D NMR spectra (HMBC and HMQC and NOESY).

Pulunasin (41) was isolated from culture cell of Hetroscyphus planus together with isoplagiochin A (37) and its structure elucidated by a combination of comparison of the spectral data with $\mathbf{3 7}$ and the analysis of HMBC and NOE spectral data [56].

Anton et al. [57] reported the isolation and structure elucidation of isoplagiochin E (42) and F (43) and a new chlorinated bis(bibenzyl), 12-chloroisoplagiochin $\mathrm{D}(\mathbf{4 4})$, together with the know isoplagiochin A (37). Plagiochin E (43) and F (43) were $C 7^{\prime}-\mathrm{C} 8^{\prime}$ dihydroisoplagiochin $\mathrm{A}$ and 10-hydroxy $\mathrm{C} 7^{\prime}-\mathrm{C} 8^{\prime}$ dihydroisoplagiochin A, respectively. The molecular formula, $\mathrm{C}_{28} \mathrm{H}_{23} \mathrm{O}_{4} \mathrm{Cl}$, of $\mathbf{4 4}$ was established by CIMS, which indicated two peaks at $m / z 458$ and 460 with a ratio of ca $100: 35$. This indicated that 44 was suggested to be isoplagiochin D monochlorinated compound. The whole structure was elucidated by comparison of the ${ }^{1} \mathrm{H}$ and ${ }^{13} \mathrm{C}$ NMR data with those of isoplagiochin $\mathrm{D}$ (40) [55]. 
Table 7

${ }^{1}$ H NMR spectral data for 2,12-dichloroisoplagiochin D (57), pusilatin A hexaacetate (60c) and pusilatin E (64)

\begin{tabular}{|c|c|c|c|}
\hline & $(57)^{*}$ & $(\mathbf{6 0 c})^{* *}$ & $(64)^{* *}$ \\
\hline $2 / 2^{\prime \prime}$ & & $6.92(\mathrm{br} \mathrm{d})^{\mathrm{a}}$ & $6.84-6.88(\mathrm{~m})$ \\
\hline 3 & $7.08(\mathrm{dd}, 8.1,2.2)$ & & \\
\hline $3 / 3^{\prime \prime}$ & & $6.69(\mathrm{br} \mathrm{s})^{\mathrm{a}}$ & $6.79-6.90(\mathrm{~m})$ \\
\hline 12 & $6.28(\mathrm{~d}, 2.2)$ & & \\
\hline $5 / 5^{\prime \prime}$ & & $6.92(\mathrm{br} \mathrm{d})^{\mathrm{a}}$ & $6.79-6.90(\mathrm{~m})$ \\
\hline \multirow[t]{2}{*}{7} & $2.47(\mathrm{~m})$ & & \\
\hline & $2.64(\mathrm{~m})$ & & \\
\hline \multirow[t]{2}{*}{$7,7^{\prime \prime}$} & & $2.87(\mathrm{~m})^{\mathrm{b}}$ & $2.91(\mathrm{~m})$ \\
\hline & & $3.00(\mathrm{~m})$ & $2.72(\mathrm{~m})$ \\
\hline \multirow[t]{2}{*}{8} & $2.64(\mathrm{~m})$ & & \\
\hline & $2.69(\mathrm{~m})$ & $2.70(\mathrm{~m})$ & \\
\hline \multirow[t]{2}{*}{$8 / 8^{\prime \prime}$} & & $3.09(\mathrm{~m})$ & $2.72(\mathrm{~m})$ \\
\hline & & $2.70(\mathrm{~m})$ & $3.03(\mathrm{~m})$ \\
\hline 10 & $6.89(\mathrm{~s})$ & & \\
\hline $10 / 10^{\prime \prime}$ & & $7.22(\mathrm{~s})$ & $7.04(\mathrm{~d}, 2.5)$ \\
\hline $12 / 12^{\prime \prime}$ & & & $6.89(\mathrm{dd}, 8.2,2.5)$ \\
\hline 13 & $7.04(\mathrm{~s})$ & & \\
\hline $13 / 13^{\prime \prime}$ & & $7.03(\mathrm{~s})$ & $7.12(\mathrm{~d}, 8.5)$ \\
\hline $3^{\prime}$ & $6.40(\mathrm{~d}, 2.2)$ & & \\
\hline $3^{\prime} / 3^{\prime \prime \prime}$ & & $5.45(\mathrm{~d}, 2.0)$ & $5.42(\mathrm{~d}, 1.9)$ \\
\hline $5^{\prime}$ & $7.12(\mathrm{dd}, 8.2,2.2)$ & & \\
\hline $5,5^{\prime \prime \prime}$ & & $6.82(\mathrm{dd}, 8.1,2.0)$ & $6.88(\mathrm{~d}, 1.9)$ \\
\hline $6^{\prime}$ & $6.84(\mathrm{~d}, 8.2)$ & & \\
\hline $6^{\prime} / 6^{\prime \prime \prime}$ & & $7.01(\mathrm{~d}, 8.1)$ & \\
\hline \multirow[t]{2}{*}{$7^{\prime}$} & $2.96(\mathrm{~m})$ & & \\
\hline & $3.02(\mathrm{~m})$ & & \\
\hline \multirow{2}{*}{$7^{\prime} / 7^{\prime \prime \prime}$} & & $2.87(\mathrm{~m})^{\mathrm{b}}$ & $2.72(\mathrm{~m})$ \\
\hline & & & $2.81(\mathrm{~m})$ \\
\hline \multirow[t]{2}{*}{$8^{\prime}$} & $2.76(\mathrm{~m})$ & & \\
\hline & $2.90(\mathrm{~m})$ & & \\
\hline \multirow[t]{2}{*}{$8^{\prime} / 8^{\prime \prime \prime}$} & & $2.62(\mathrm{~m})$ & $2.72(\mathrm{~m})$ \\
\hline & & $2.87(\mathrm{~m})^{\mathrm{b}}$ & \\
\hline $10^{\prime}$ & $6.72(\mathrm{~d}, 7.4)$ & & \\
\hline $10^{\prime} / 10^{\prime \prime \prime}$ & & $6.44($ br d, 7.8$)$ & $6.35(\mathrm{dd}, 7.7,1.6)$ \\
\hline $11^{\prime}$ & $7.02(\mathrm{~d}, 7.2)$ & & \\
\hline $11^{\prime} / 11^{\prime \prime \prime}$ & & $6.95(\mathrm{~d}, 7.8)$ & $6.84(\mathrm{~d}, 7.7)$ \\
\hline $14^{\prime}$ & 6.63 (br s) & & \\
\hline $14^{\prime} / 14^{\prime \prime \prime}$ & & $6.66(\mathrm{~d}, 1.5)$ & $6.47(\mathrm{~d}, 1.6)$ \\
\hline $1^{\prime} / 1^{\prime \prime \prime}-\mathrm{OH}$ & & & $6.23(\mathrm{~s})$ \\
\hline $13 / 13^{\prime \prime \prime}-\mathrm{OH}$ & & & $4.82(\mathrm{~s})$ \\
\hline 11/11'-OMe & & & $3.91(\mathrm{~s})$ \\
\hline \multirow[t]{3}{*}{ OAc } & & $2.32(\mathrm{~s})$ & \\
\hline & & $2.12(\mathrm{br} \mathrm{s})$ & \\
\hline & & $1.99(\mathrm{~s})$ & \\
\hline
\end{tabular}

\footnotetext{
${ }^{\mathrm{a}}$ Measured in $600 \mathrm{MHz}\left(\mathrm{MeOH}-\mathrm{d}_{4}\right) .{ }^{\mathrm{b}}$ Measured in $400 \mathrm{MHz}\left(\mathrm{CDCl}_{3}\right) .{ }^{\mathrm{c}}$ Overlapped signal
} 
Table 8

${ }^{13}$ C NMR data for riccardin A (1a), B (2), C (3), marchantin A (8a), its trimethyl ether (8c), marchantin B (9), marchantin C (10), marchantin $\mathrm{H}(\mathbf{1 6})$ and marchantin $\mathrm{J}$ trimethyl ether (18a)

\begin{tabular}{|c|c|c|c|c|c|c|c|c|c|}
\hline$\overline{\mathrm{C}}$ & $(\mathbf{1 a})^{*}$ & $(2)^{*}$ & $(3)^{* *}$ & $(\mathbf{8 a})^{*}$ & $(\mathbf{8 c})^{*}$ & $(9)^{*}$ & $(\mathbf{1 0})^{*}$ & $(16)^{*}$ & $(18 \mathbf{a})^{*}$ \\
\hline 1 & 152.3 & 154.8 & 152.5 & 152.9 & 153.4 & 153.6 & 152.7 & 152.8 & 153.3 \\
\hline 2 & 122.2 & 116.6 & 122.3 & 121.2 & 121.1 & 121.2 & 121.1 & 121.3 & 121.8 \\
\hline 3 & 129.0 & 130.1 & 129.2 & 129.5 & 129.4 & 129.6 & 129.4 & 129.7 & 129.4 \\
\hline 4 & 139.6 & 135.2 & 139.8 & 139.0 & 138.3 & 137.9 & 138.8 & 139.2 & 139.2 \\
\hline 5 & 129.0 & 130.1 & 129.2 & 129.5 & 129.4 & 129.6 & 129.4 & 129.7 & 129.4 \\
\hline 6 & 122.2 & 116.6 & 122.3 & 121.2 & 121.1 & 121.2 & 121.1 & 121.3 & 121.8 \\
\hline 7 & $38.3^{\mathrm{a}}$ & $38.2^{\mathrm{b}}$ & 38.1 & 35.2 & 35.5 & 35.7 & 35.1 & $35.9^{\mathrm{c}}$ & 36.1 \\
\hline 8 & 35.3 & $37.5^{\mathrm{b}}$ & 35.0 & 30.2 & 29.9 & 29.7 & 30.1 & 30.0 & 30.3 \\
\hline 9 & 143.2 & 143.4 & 143.7 & 136.1 & 136.5 & 127.3 & 136.0 & 127.3 & 136.8 \\
\hline 10 & 116.1 & 125.0 & 117.5 & 121.9 & 122.3 & 120.5 & 121.7 & 121.6 & 122.7 \\
\hline 11 & 159.5 & 129.9 & 155.9 & 126.0 & 125.2 & 112.5 & 125.8 & 112.4 & 125.4 \\
\hline 12 & 112.5 & 118.4 & 114.3 & 114.3 & 110.0 & 143.9 & 114.4 & 143.5 & 110.1 \\
\hline 13 & 132.4 & 154.2 & 132.8 & 148.6 & 152.3 & 137.6 & 148.6 & 135.7 & 152.3 \\
\hline 14 & 128.0 & 120.7 & 128.2 & 139.6 & 141.2 & 140.7 & 139.6 & 140.0 & 140.9 \\
\hline $1^{\prime}$ & 143.1 & 145.5 & 143.7 & 130.6 & 136.5 & 131.9 & 143.1 & 143.5 & 137.1 \\
\hline $2^{\prime}$ & 146.1 & 141.3 & 146.3 & 146.4 & 152.2 & 147.4 & 146.0 & 146.1 & 152.1 \\
\hline $3^{\prime}$ & 115.9 & 121.0 & 116.0 & 107.9 & 109.8 & 108.4 & 115.5 & 115.6 & 109.2 \\
\hline $4^{\prime}$ & 132.9 & 133.8 & 133.1 & 132.4 & 136.0 & 132.1 & 132.5 & 132.6 & 136.5 \\
\hline $5^{\prime}$ & 122.0 & 125.2 & 122.1 & 109.3 & 106.0 & 109.5 & 122.2 & 122.4 & 101.6 \\
\hline $6^{\prime}$ & 114.8 & 115.9 & 114.9 & 144.1 & 153.1 & 145.2 & 115.1 & 115.0 & 153.7 \\
\hline $7^{\prime}$ & $37.9^{\mathrm{a}}$ & $37.4^{\mathrm{b}}$ & 37.1 & 34.0 & 34.6 & 34.2 & 33.7 & 34.2 & 82.9 \\
\hline $8^{\prime}$ & $37.2^{\mathrm{a}}$ & $38.1^{\mathrm{b}}$ & 37.6 & 35.4 & 35.3 & 35.7 & 35.5 & $35.8^{\mathrm{c}}$ & 44.4 \\
\hline $9^{\prime}$ & 141.7 & 136.0 & 141.9 & 143.0 & 141.7 & 142.6 & 142.6 & 143.2 & 138.6 \\
\hline $10^{\prime}$ & 121.5 & 121.0 & 121.7 & 115.4 & 115.2 & 115.7 & 115.4 & 115.6 & 116.4 \\
\hline $11^{\prime}$ & 131.2 & 115.0 & 131.4 & 156.6 & 157.9 & 157.6 & 156.8 & 156.6 & 157.7 \\
\hline $12^{\prime}$ & 124.3 & 143.0 & 124.4 & 112.0 & 112.2 & 112.6 & 111.9 & 112.2 & 112.2 \\
\hline $13^{\prime}$ & 151.6 & 145.6 & 151.8 & 128.8 & 128.0 & 128.4 & 128.6 & 129.0 & 127.7 \\
\hline $14^{\prime}$ & 115.9 & 115.8 & 116.0 & 123.1 & 121.6 & 122.4 & 122.9 & 123.5 & 123.5 \\
\hline
\end{tabular}

${ }^{*}$ Measured in $100 \mathrm{MHz}$ (in $\mathrm{CDCl}_{3}$ ).

** Measured in $150 \mathrm{MHz}\left(\mathrm{CDCl}_{3}\right)$.

a,b,c May be interchangeable in each vertical column.

Furthermore, Martin et al. [58] reported the isolation of 10 chlorinated bis(bibenzyls), bazzanin A-J (45-54) from Bazzania trilobata along with bazzanin K (55) which possesses bibenzylphenanthrene skeleton. Neither nonchlorinated bibenzyl nor bisbibenzyls have been isolated from this European species. The structure elucidation of these halogen-containing compounds was carried out by high-resolution mass spectrometry as well as 2D-NMR spectra $\left({ }^{1} \mathrm{H}-{ }^{1} \mathrm{H},{ }^{1} \mathrm{H}^{-13} \mathrm{C}\right.$ COSY, HMBC, NOESY). Martin et al. [58] used the name, bazzanin for the new compounds, however, these are isoplagiochin $\mathrm{C}(\mathbf{3 9})$ and isoplgiochin $\mathrm{D}(\mathbf{4 0})$ [55] series with one to six chlorine atom in each molecule.

The Japanese stem-leafy liverwort Herbertus sakuraii produces two optically active chlorinated compounds, (-)-12,10'-dichloroisoplagiochin $\mathrm{C}(\mathbf{5 6})\left([\alpha]_{\mathrm{D}}^{21}-19.1^{\circ}\left(\mathrm{c} 0.38, \mathrm{CHCl}_{3}\right)\right.$ and $\mathrm{CD}: \lambda_{\mathrm{nm}}$ $\left.(\Delta \varepsilon): 322(+7.80), 282(-7.47), 244(+48.08), 214(-157.72)\left(\mathrm{c} 6.1 \times 10^{-6}, \mathrm{EtOH}\right)\right)$ and $(-)-12,7^{\prime}-$ dichloroisoplagiochin $\mathrm{D}(\mathbf{5 8})\left([\alpha]_{\mathrm{D}}^{20}-2.7^{\circ}(\mathrm{c} 0.47, \mathrm{MeOH})\right.$ and $\mathrm{CD}: \lambda_{\mathrm{nm}}(\Delta \varepsilon): 300(+0.74), 281(-0.39)$, 
Table 9

${ }^{13}$ C NMR data for ptychantol A (27), C (29), plagiochin A (33), isoplagiochin A (37), C (39), D (40) and 2,12-dichloroisoplagiochin D (57)

\begin{tabular}{|c|c|c|c|c|c|c|c|}
\hline$\overline{\mathrm{C}}$ & $(27)^{*}$ & $(\mathbf{2 9})^{*}$ & $(\mathbf{3 3})^{* *}$ & $(37)^{* * *}$ & $(39)^{*}$ & $(40)^{*}$ & $(57)^{*}$ \\
\hline 1 & 153.7 & 154.1 & 154.5 & 152.9 & 150.8 & 151.6 & 148.7 \\
\hline 2 & 122.4 & 122.2 & $123.3^{\mathrm{a}}$ & 117.0 & 116.8 & 116.1 & 122.5 \\
\hline 3 & 131.4 & 132.8 & 129.6 & 129.1 & 128.0 & 128.0 & 128.7 \\
\hline 4 & 138.5 & 135.7 & 139.2 & 136.6 & 135.8 & 136.0 & 137.2 \\
\hline 5 & 131.4 & 131.4 & 129.6 & 134.1 & 133.8 & 134.3 & 133.1 \\
\hline 6 & 122.4 & 122.2 & $122.1^{\mathrm{a}}$ & 128.0 & 126.8 & 127.6 & 130.6 \\
\hline 7 & 35.9 & 44.7 & $35.2^{\mathrm{b}}$ & 37.6 & 37.7 & 38.1 & 38.3 \\
\hline 8 & 37.0 & 75.4 & $29.3^{c}$ & 35.2 & 38.3 & 39.1 & 39.0 \\
\hline 9 & 143.6 & 147.1 & 129.7 & 137.9 & 144.0 & 144.0 & 143.2 \\
\hline 10 & 121.9 & 119.6 & 111.9 & 111.7 & 115.9 & 116.0 & 117.7 \\
\hline 11 & 129.9 & 130.0 & 145.7 & 156.2 & 156.7 & 157.3 & 153.3 \\
\hline 12 & 109.9 & 110.9 & 142.3 & 115.3 & 113.3 & 113.3 & 118.7 \\
\hline 13 & 160.3 & 160.2 & 117.2 & 124.6 & 131.9 & 132.4 & 132.9 \\
\hline 14 & 118.7 & 116.6 & 132.9 & 145.8 & 128.3 & 129.5 & 132.1 \\
\hline $1^{\prime}$ & 147.5 & 147.6 & 130.5 & 154.1 & 152.4 & 152.2 & 152.2 \\
\hline $2^{\prime}$ & 149.8 & 149.6 & 149.9 & 127.4 & 126.0 & 126.0 & 125.7 \\
\hline $3^{\prime}$ & 109.8 & 109.9 & 106.6 & 133.8 & 133.4 & 133.9 & 134.8 \\
\hline $4^{\prime}$ & 129.8 & 129.8 & 131.4 & 130.8 & 129.6 & 133.9 & 134.8 \\
\hline $5^{\prime}$ & 124.2 & 124.2 & 108.4 & 109.3 & 130.5 & 129.3 & 130.4 \\
\hline $6^{\prime}$ & 116.7 & 116.8 & 144.8 & 117.7 & 117.0 & 117.0 & 116.7 \\
\hline $7^{\prime}$ & 128.6 & 128.8 & $34.2^{\mathrm{b}}$ & 131.4 & 130.0 & 36.1 & 37.0 \\
\hline $8^{\prime}$ & 119.7 & 119.7 & $30.3^{c}$ & 129.4 & 128.9 & 38.5 & 39.3 \\
\hline $9^{\prime}$ & 132.1 & 132.1 & 139.5 & 142.5 & 140.2 & 142.5 & 143.8 \\
\hline $10^{\prime}$ & 144.7 & 144.6 & 130.1 & 117.0 & 120.3 & 117.4 & 122.1 \\
\hline $11^{\prime}$ & 125.0 & 124.9 & 132.3 & 161.5 & 132.0 & 131.9 & 132.5 \\
\hline $12^{\prime}$ & 116.4 & 116.5 & 110.8 & 112.1 & 127.2 & 127.2 & 126.9 \\
\hline $13^{\prime}$ & 155.8 & 155.9 & 155.0 & 131.6 & 154.4 & 155.1 & 155.7 \\
\hline $14^{\prime}$ & 111.8 & 111.7 & 113.4 & 123.5 & 115.4 & 121.5 & 118.1 \\
\hline
\end{tabular}

${ }^{*}$ Measured in $150 \mathrm{MHz}$ (acetone- $\mathrm{d}_{6}$ ).

${ }^{* *}$ Measured in $150 \mathrm{MHz}\left(\mathrm{CDCl}_{3}-\mathrm{MeOH}-\mathrm{d}_{4}\right)$.

*** Measured in $125 \mathrm{MHz}\left(\mathrm{MeOH}-\mathrm{d}_{4}\right)$.

${ }^{a, b, c}$ May be interchangeable in each vertical column.

$\left.234(+5.34)\left(\mathrm{c} 9.7 \times 10^{-6}, \mathrm{EtOH}\right)\right)$ and an optically inactive compound, 2,12-dichloroisoplagiochin D (57), together with two known optically active isoplagiochin C (39) and isoplagiochin D (40). The stereochemistry of 57 was established by a combination of the ${ }^{1} \mathrm{H}$ and ${ }^{13} \mathrm{C}$ NMR analysis (Tables 7 and 9) including 2D-NMR and X-ray crystallographic analysis. The ORTEP drawing (Fig. 8) shows that 57 is present as a chathrate compound formed by two molecules of compound $\mathbf{5 7}$ and dichloromethane as the solvent of recrystallization to give the racemic crystal. Their absolute configuration remained to be clarified. The optically inactive isoplagiochin C (39) and D (40) have already been isolated from Plagiochila fruticosa [55]. However, the present same compounds showed positive optical rotation $\left([\alpha]_{D}\right.$ $+74.8^{\circ}$ (c $0.67, \mathrm{MeOH}$ for 39; $+47.5^{\circ}$ (c $\left.0.67, \mathrm{MeOH}\right)$ for 40) and Cotton effects $\left[\lambda_{\mathrm{nm}}(\Delta \varepsilon)\right.$ : 231 $(+24.4), 213(-63.2)\left(\mathrm{c} 1.6 \times 10^{-5}, \mathrm{EtOH}\right)$ for 39; $252(+2.4), 225(+22.5)\left(\mathrm{c} 1.2 \times 10^{-5}, \mathrm{EtOH}\right.$ for 40)], but their absolute configuration has not been established yet. Two optically inactive chlorinated 
Table 10

${ }^{13} \mathrm{C}$ NMR data for pusilatin A tetraacetate (60c) and pusilatin E (64)

\begin{tabular}{lccccc}
\hline $\mathrm{C}$ & $(\mathbf{6 0 c})^{*}$ & $(\mathbf{6 4})^{* *}$ & $\mathrm{C}$ & $(\mathbf{6 0 c})^{*}$ & $(\mathbf{6 4})^{* *}$ \\
\hline $1 / 1^{\prime \prime}$ & 152.9 & 152.7 & $1^{\prime} / 1^{\prime \prime \prime}$ & 137.9 & 140.4 \\
$2 / 2^{\prime \prime}$ & $128.8^{\mathrm{a}}$ & $122.6^{\mathrm{c}}$ & $2^{\prime} / 2^{\prime \prime \prime}$ & 150.6 & 147.3 \\
$3 / 3^{\prime \prime}$ & $129.2^{\mathrm{b}}$ & $129.4^{\mathrm{d}}$ & $3^{\prime} / 3^{\prime \prime \prime}$ & 117.7 & 115.5 \\
$4 / 4^{\prime \prime}$ & 139.4 & 139.8 & $4^{\prime} / 4^{\prime \prime \prime}$ & 139.6 & 133.2 \\
$5 / 5^{\prime \prime}$ & $129.2^{\mathrm{b}}$ & $129.4^{\mathrm{d}}$ & $5^{\prime} / 5^{\prime \prime \prime}$ & 122.9 & 124.2 \\
$6 / 6^{\prime \prime}$ & $128.8^{\mathrm{a}}$ & $122.6^{\mathrm{c}}$ & $6^{\prime} / 6^{\prime \prime \prime}$ & 37.2 & 125.1 \\
$7 / 7^{\prime \prime}$ & 38.0 & 38.3 & $7^{\prime} / 7^{\prime \prime \prime}$ & 37.1 & 37.2 \\
$8 / 8^{\prime \prime}$ & 35.2 & 35.3 & $8^{\prime} / 8^{\prime \prime \prime}$ & 147.4 & 37.7 \\
$9 / 9^{\prime \prime}$ & 148.1 & 143.5 & $9^{\prime} / 9^{\prime \prime \prime}$ & 127.4 & 142.0 \\
$10 / 10^{\prime \prime}$ & 124.0 & 116.3 & $10^{\prime} / 10^{\prime \prime \prime}$ & 132.3 & 121.7 \\
$11 / 11^{\prime \prime}$ & 142.1 & 159.9 & $11^{\prime} / 11^{\prime \prime \prime}$ & 130.6 & 131.5 \\
$12 / 12^{\prime \prime}$ & 127.8 & 112.7 & $12^{\prime} / 12^{\prime \prime \prime}$ & 141.5 & 124.6 \\
$13 / 13^{\prime \prime}$ & 132.3 & $13^{\prime} / 13^{\prime \prime \prime}$ & 122.5 & 151.9 \\
$14 / 14^{\prime \prime}$ & 134.6 & $14^{\prime} / 14^{\prime \prime \prime}$ & 20.8 & 116.6 \\
& & 128.1 & $11-\mathrm{OAc}$ & 169.1 & \\
& & & & 20.7 & 169.1 \\
\end{tabular}

${ }^{*}$ Measured in $150 \mathrm{MHz}\left(\mathrm{DMSO}_{-} \mathrm{d}_{6}\right)$.

** Measured in $150 \mathrm{MHz}\left(\mathrm{CDCl}_{3}\right)$.

a,b,c,d May be interchangeable in each vertical column.

bis(bibenzyls), 12-chloroisoplagochin D (44) and 2,12-dichloroisoplagiochin D (57) have also been isolated from Mastigophora diclados belonging to the Mastigophoroideae [59].

The methanol extract of a small thalloid liverwort, Blasia pussila was fractionated to give four unique dimeric cyclic bis(bibenzyl) derivatives, pusilatin A-D (60a, 61-63), together with riccardin C (3) and riccardin $\mathrm{F}(\mathbf{6})$, shikimic acid, lunularic acid (66) and lunularin (67) $[19,20,53,54]$. The ${ }^{13} \mathrm{C}$ NMR spectrum contained 28 signals including four benzylic methylene signals. The ${ }^{1} \mathrm{H}$ NMR spectrum of $\mathbf{6 0 a}$ showed the presence of 12 protons on benzene rings at $\delta$ 5.37-7.14 and four benzylic methylenes at $\delta 2.61-2.92(8 \mathrm{H})$. The coupling pattern of $\mathbf{6 0 a}$ resembled that of riccardin $\mathrm{C}(\mathbf{3})$ except for the $\mathrm{B}$ ring protons. Sine 60a gave a parent ion peak in the positive FAB-MS spectrum at $m / z 869[\mathrm{M}+\mathrm{Na}]^{+}$and $846[\mathrm{M}]^{+}$, compound 60a might be a symmetrical dimer of riccaridn C. The methylation and acetylation of 60a gave a hexamethyl ether $(\mathbf{6 0 b})$ and a hexaacetate $(\mathbf{6 0 c})$. Compound $(\mathbf{6 0 b})$ showed the NOEs between (i) $\mathrm{H}-10 / 10^{\prime \prime}$ and 11/11" $-\mathrm{OME}$, (ii) $\mathrm{H}-6 / \mathrm{H}-6^{\prime \prime \prime}$ and $\mathrm{H}-1^{\prime} / 1^{\prime \prime \prime}-\mathrm{OMe}$, and (iii) $\mathrm{H}-14^{\prime} / \mathrm{H}-14^{\prime \prime \prime}$ and $\mathrm{H}-$ $13^{\prime} / 13^{\prime \prime \prime}$-OMe in the difference NOE spectral experiments. On the basis of the above spectral data as well as analysis of ${ }^{1} \mathrm{H}-{ }^{1} \mathrm{H}-\mathrm{COSY}, \mathrm{HMQC}$ and $\mathrm{HMBC}$ spectral data of $\mathbf{6 0 \mathbf { b }}$, the structure of pusilatin A (60a) was suggested to be riccardin $\mathrm{C}(\mathbf{3})$ dimer with a $\mathrm{C} 12-\mathrm{C}-12^{\prime \prime}$ phenyl linkage. The conclusive evidence for the structure of pusilatin A was obtained by X-ray crystallographic analysis of its hexaacetate $(\mathbf{6 0 c})$. The ORTEP drawing has been shown in Fig. 9. The structures of the other dimeric bis(bibenzyls) (61-63) have been determined by an extensive 2D NMR and FAB-MS spectrometry.

The similar dimeric bis(bibenzyl), pusilatin E (64) has been isolated from Riccarida mulitifida and its structure was elucidated as the monomethyl ether of pusilatin B (61), because demethylation of $\mathbf{6 4}$ with 
Table 11

${ }^{1} \mathrm{H}(600 \mathrm{MHz})$ and ${ }^{13} \mathrm{C}$ NMR spectral data (150 MHz) for (+)-cavicularin (65)

\begin{tabular}{|c|c|c|c|c|}
\hline Position & $\mathrm{H}$ & $\mathrm{C}$ & HMBC & NOE \\
\hline 1 & & 153.8 & $2,3,5,6-\mathrm{H}$ & $8-\mathrm{H}$ \\
\hline 2 & $6.10(\mathrm{dd}, 8.6,2.7)^{\mathrm{a}}$ & 115.1 & $6-\mathrm{H}$ & \\
\hline 3 & $6.46(\mathrm{dd}, 8.6,2.2)^{\mathrm{b}}$ & 127.8 & $5-\mathrm{H}$ & \\
\hline 4 & & 135.0 & $2,6-\mathrm{H}$ & \\
\hline 5 & $6.15(\mathrm{dd}, 8.3,2.2)^{\mathrm{b}}$ & 130.0 & $3-\mathrm{H}$ & 7-H \\
\hline 6 & $6.71(\mathrm{dd}, 8.3,2.7)^{\mathrm{a}}$ & 117.8 & $2-\mathrm{H}$ & \\
\hline \multirow[t]{2}{*}{7} & $2.55(\mathrm{ddd}, 17.6,13.4,4.4)$ & 38.1 & $3,5-\mathrm{H}$ & $5,8,10-\mathrm{H}$ \\
\hline & $2.96(\mathrm{~m})^{\mathrm{c}}$ & & & \\
\hline \multirow[t]{2}{*}{8} & $2.28(\mathrm{ddd}, 17.6,13.4,4.4)$ & 37.4 & $10-\mathrm{H}$ & $3,7-\mathrm{H}$ \\
\hline & $2.94(\mathrm{~m})^{\mathrm{c}}$ & & & \\
\hline 9 & & 141.6 & $13 \mathrm{H}$ & \\
\hline 10 & $6.88(\mathrm{~d}, 2.7)$ & 116.9 & $12-\mathrm{H}$ & \\
\hline 11 & & 155.5 & $13-\mathrm{H}$ & \\
\hline 12 & $6.75(\mathrm{dd}, 8.3,2.7)$ & 114.7 & $10-\mathrm{H}$ & \\
\hline 13 & $6.84(\mathrm{~d}, 8.3)$ & 131.6 & & $11^{\prime}-\mathrm{H}$ \\
\hline 14 & & 128.9 & $10,12,11-\mathrm{H}$ & \\
\hline $1^{\prime}$ & & 147.8 & $5^{\prime}-\mathrm{H}, 1^{\prime}-\mathrm{OH}$ & \\
\hline $2^{\prime}$ & & 138.5 & $6^{\prime}-\mathrm{H}, 1^{\prime}-\mathrm{OH}$ & \\
\hline $3^{\prime}$ & & 123.0 & $5^{\prime}, 11^{\prime}-\mathrm{H}$ & \\
\hline $4^{\prime}$ & & 131.7 & $6^{\prime}-\mathrm{H}$ & \\
\hline $5^{\prime}$ & $6.98(\mathrm{~d}, 8.1)$ & 123.0 & & $7^{\prime}-\mathrm{H}$ \\
\hline $6^{\prime}$ & $6.94(\mathrm{~d}, 8.1)$ & 113.0 & $1^{\prime}-\mathrm{OH}$ & \\
\hline \multirow[t]{2}{*}{$7^{\prime}$} & $2.66(\mathrm{~m})^{\mathrm{c}}$ & 30.2 & $5^{\prime}-\mathrm{H}$ & $5^{\prime}, 8^{\prime}-\mathrm{H}$ \\
\hline & $2.76(\mathrm{~m})$ & & & \\
\hline $8^{\prime}$ & $2.66(\mathrm{~m})^{\mathrm{c}}$ & 30.5 & $14^{\prime}-\mathrm{H}$ & $7^{\prime}, 14^{\prime}-\mathrm{H}$ \\
\hline $9^{\prime}$ & & 140.5 & $11^{\prime}-\mathrm{H}$ & \\
\hline $10^{\prime}$ & & 124.0 & $14^{\prime}-\mathrm{H}$ & \\
\hline $11^{\prime}$ & $6.40(\mathrm{~s})$ & 131.1 & & $13-\mathrm{H}$ \\
\hline $12^{\prime}$ & & 124.0 & $13,14^{\prime}-\mathrm{H}, 13^{\prime}-\mathrm{OH}$ & \\
\hline $13^{\prime}$ & & 150.2 & $11^{\prime}, 14^{\prime}-\mathrm{H}, 13^{\prime}-\mathrm{OH}$ & \\
\hline $14^{\prime}$ & $6.68(\mathrm{~s})$ & 113.2 & $13^{\prime}-\mathrm{OH}$ & $8^{\prime}-\mathrm{H}$ \\
\hline $11-\mathrm{OH}$ & 4.88 (br s) & & & \\
\hline $13^{\prime}-\mathrm{OH}$ & $4.75(\mathrm{~s})$ & & & \\
\hline
\end{tabular}

${ }^{a}$ May be interchangeable in each vertical column.

${ }^{\mathrm{b}}$ Overlapped signals.

$\mathrm{BBr}_{3}$ gave 61. The ${ }^{1} \mathrm{H}$ and ${ }^{13} \mathrm{C}$ NMR spectral data of $\mathbf{6 4}$ are indicated in Tables 7 and 10. Compound 63 was synthesized by coupling reaction of riccardin $\mathrm{A}(3)$ with $\mathrm{Mn}(\mathrm{OAc})_{3}$ [60].

Cavicularia densa, which belongs to the same Blasiaceae family as $B$. pussila produces an interesting phenathrene-bibenzyl derivative, cavicularin (65) and its structure was established by a combination of ${ }^{1} \mathrm{H}$ and ${ }^{13} \mathrm{C}$ NMR spectral analysis (Table 11 and Fig. 10) including 2D-NMR (Fig. 11) and X-ray crystallographic analysis (Fig. 12) [61]. It was shown that the phenathrene-bibenzyl skeleton has a highly strained structure and the benzene ring A was twisted (Figs 12-14). The absolute structure of $\mathbf{6 5}$ was restricted to $65 \mathrm{a}$ or $\mathbf{6 5 b}$ by X-ray crystallographic analysis. Although the structure of $\mathbf{6 5}$ has no chiral center, its specific optical rotation showed $[\alpha]_{\mathrm{D}}+168.2^{\circ}(c, 0.25 \mathrm{MeOH})$ and the CD Cotton effect 


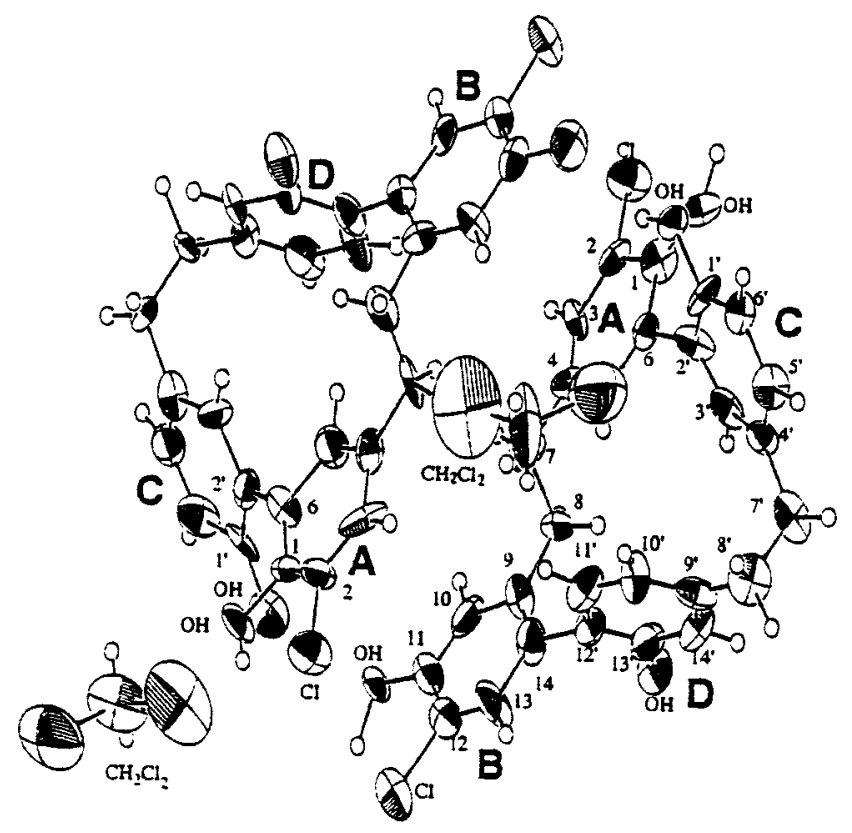

Fig. 8. ORTEP drawing of 2,12-dichloroisoplagiochin D (57).

due to the $\pi-\pi^{*}$ transition of the asymmetic aryls $\left[\lambda_{\mathrm{nm}} 312(\Delta \varepsilon+4.6), 280(+2.6), 255(-2.6), 208\right.$ $(+24.6)\left(\mathrm{c} 2.5 \times 10^{-5} \mathrm{~g} / \mathrm{ml}, \mathrm{MeOH}\right)$. This phenomenon suggested that $65 \mathrm{a}$ possessed both planar and axial chirality.

\section{Biological activity of cyclic bis(bibenzyls) [5,7-11]}

Riccardin A (1a) and (2) showed cytotoxic activity against KB cell at a concentration of 10 and $12 \mu \mathrm{g} / \mathrm{ml}$, respectively. Marchantin A (8a), B (9), and C (10) also showed the same activity as mentioned above at a concentration of $\mathrm{ED}_{50} 3.7-20 \mu \mathrm{M}$ and anti-HIV-1 at 5.30-23.7 $\mu \mathrm{g} / \mathrm{ml}$. The dimeric cyclic bis(bibenzyls), pusilatin B (61) and C (62) showed DNA polymerase $\beta$ inhibitory activity at a concentration of $\mathrm{IC}_{50} 13.0$ and $5.16 \mu \mathrm{M}$ and cytotoxic activity against $\mathrm{KB}$ cell at 13.1 and $13.0 \mu \mathrm{g} / \mathrm{ml}$, respectively.

Marchantin A (8a) also indicated antimicrobial and antifungal activity against various bacteria and fungous, particularly, it inhibited the fungi Tricophyton mentagraphytes at MIC $3.13 \mu \mathrm{g} / \mathrm{ml}$. Compounds (1a) and (8a), marchantin D (12) and E (13) indicated inhibitory activity against 5-lipoxigenase and calmoduoin. On the other hand, compound 8a, 9, 13, isoriccardin $\mathrm{C}(\mathbf{2 3})$ and riccardin $\mathrm{C}(\mathbf{3})$ showed weak cyclooxygenase inhibitory activity $\left(\mathrm{IC}_{50} 45.2-58.0 \mu \mathrm{M}\right)$. Isomarchantin $\mathrm{C}(\mathbf{2 2})$ showed 95 and 93\% inhibition of cathepcin L and B at $10 \mu \mathrm{M}$, respectively. Plagiochin A (33) showed neurotrophic activity at $1 \mu \mathrm{M}$. Marchantin A (8a) increased coronary blood flow $(2.5 \mathrm{ml} / \mathrm{min}$ at $100 \mu \mathrm{g})$.

\section{Total synthesis of cyclic bis(bibenzyls)}

Riccardin A-C (1a-3) have been synthesized by Gottsegen et al. [62], using a combination of Ullmann, Wittig and Wurtz reactions and $\mathrm{Ni}(0)$-assisted intermolecular coupling reaction. Kodama's group [63- 


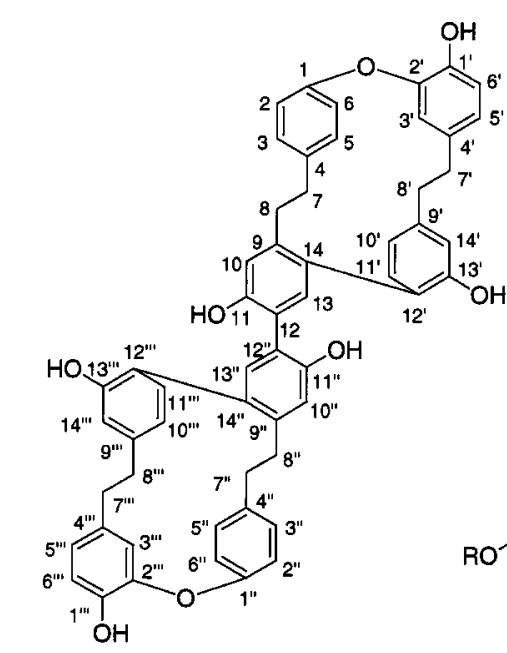

$60 \mathrm{a} R=\mathrm{H}$

$60 b \mathrm{R}=\mathrm{Me}$

$60 \mathrm{~b} R=\mathrm{Me}$
$60 \mathrm{c} R=\mathrm{Ac}$

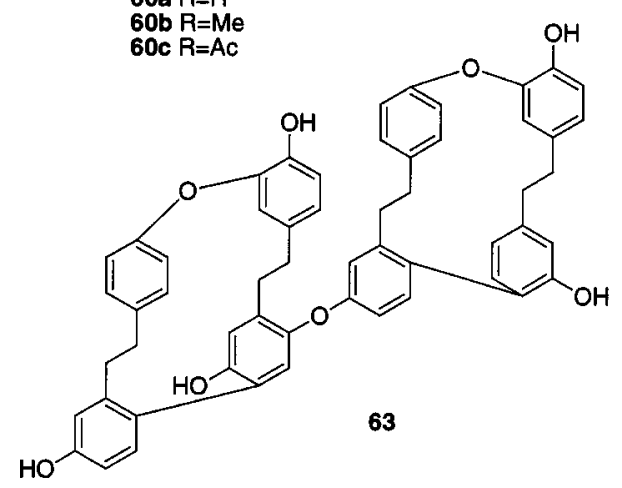

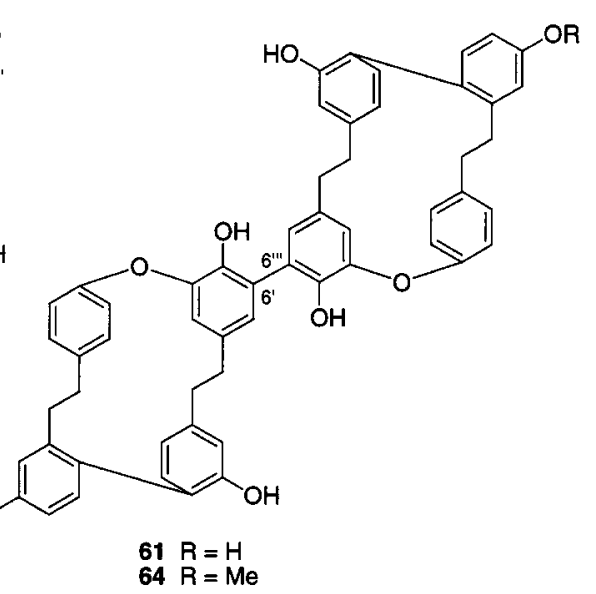
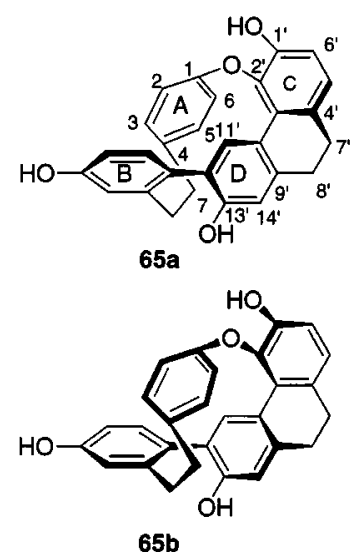
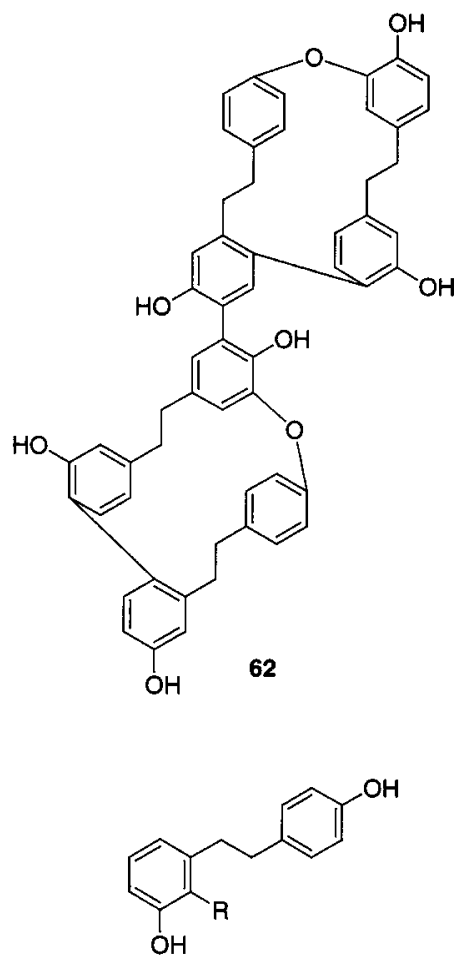

66a $\mathrm{R}=\mathrm{COOH}$ 66b $\mathrm{R}=\mathrm{H}$

Chart 4. Pusilatin-type cyclic bis(bibenzyls), bibenzyl-phenanthrene and bibenzyls isolated from the liverworts.

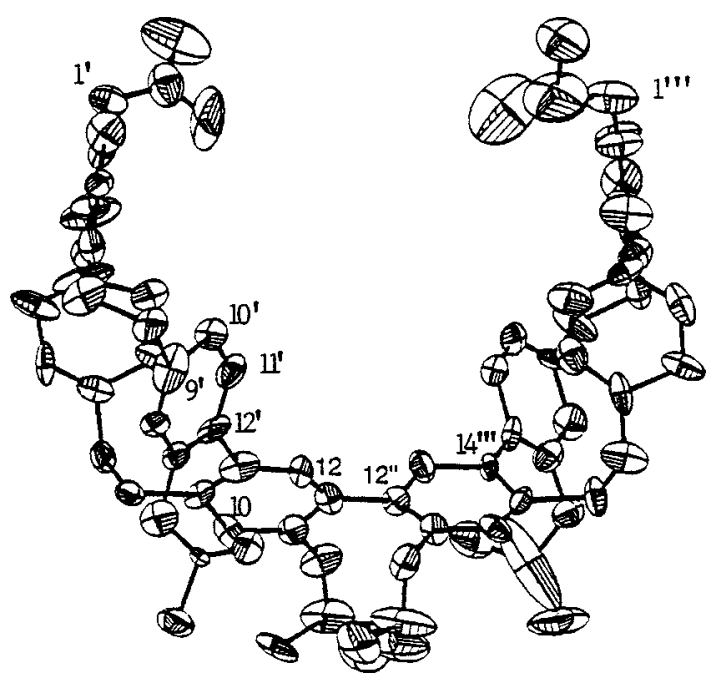

Fig. 9. ORTEP drawing of pusilatin A hexaacetate (60c). 

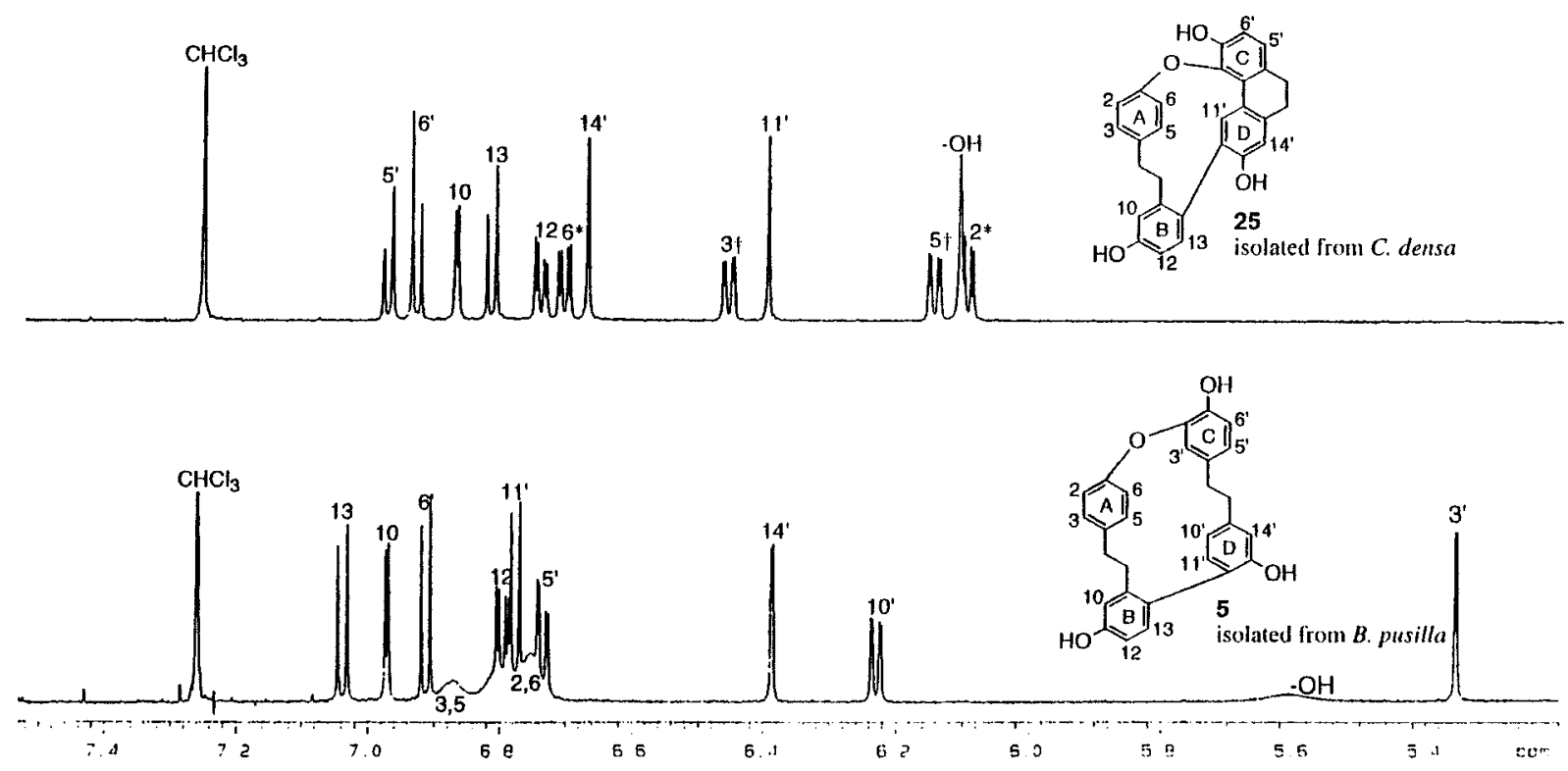

Fig. 10. $600 \mathrm{MHz}{ }^{1} \mathrm{H}$ NMR spectra of (+)-cavicularin (65) and riccardin $\mathrm{C}(\mathbf{3})$ in $\mathrm{CDCl}_{3}$.

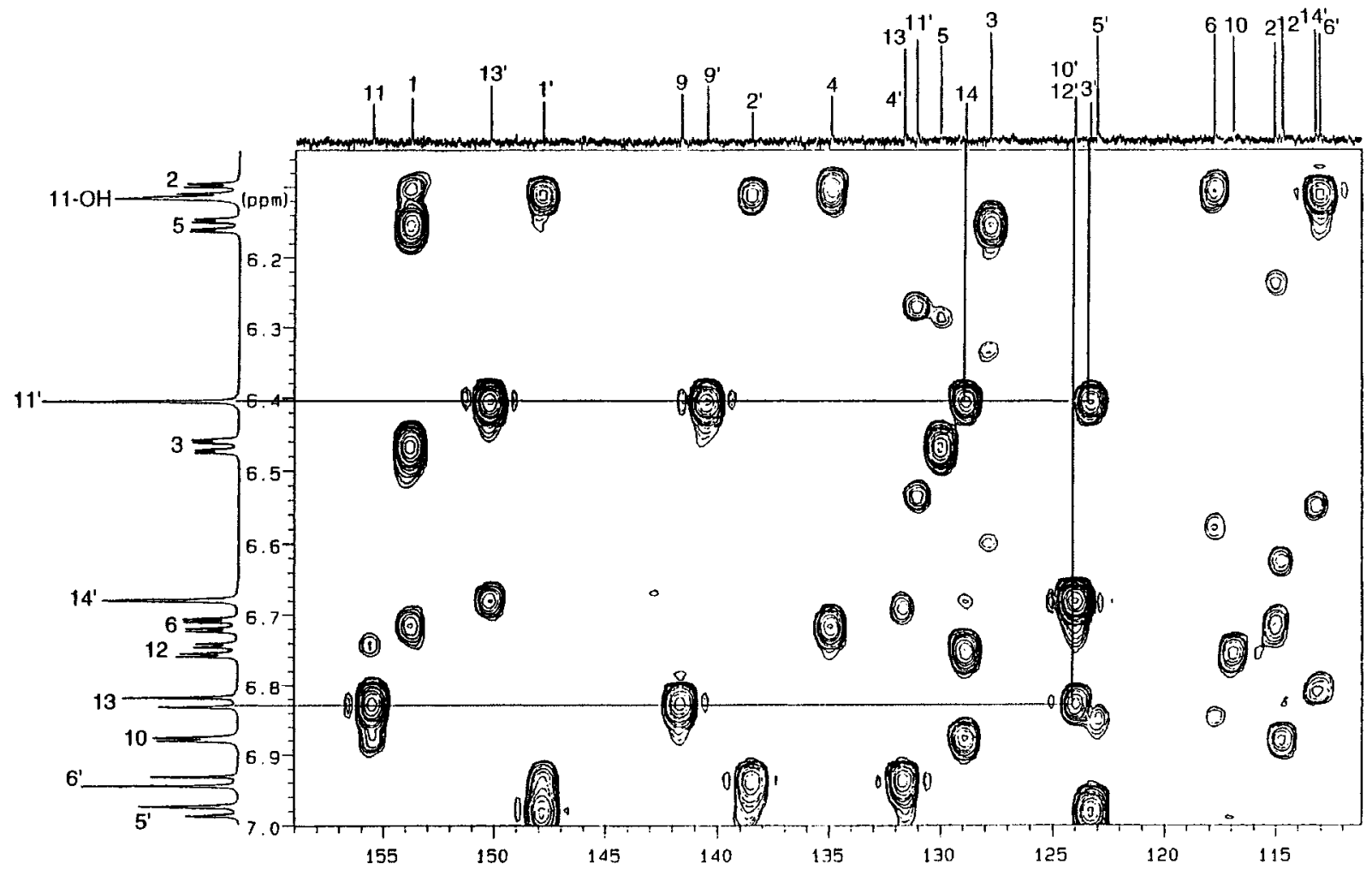

Fig. 11. $600 \mathrm{MHz}$ HMBC spectrum of cavicularin (65). 

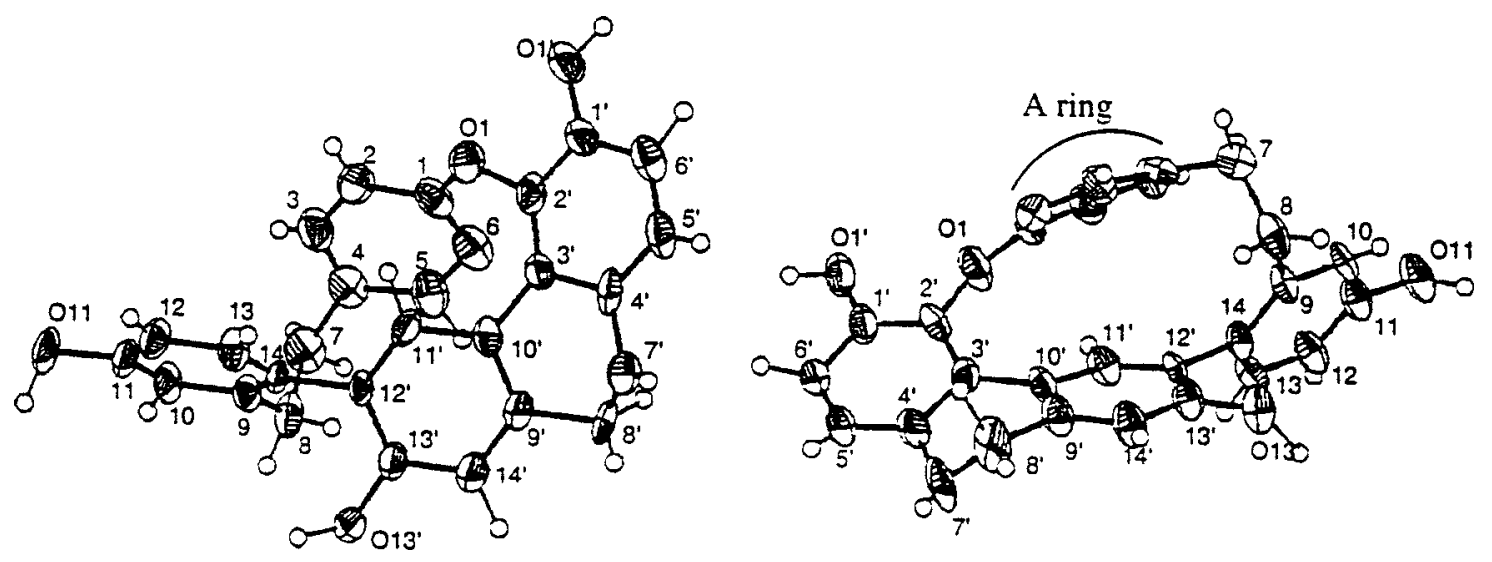

Fig. 12. ORTEP drawing of cavicularin (65).
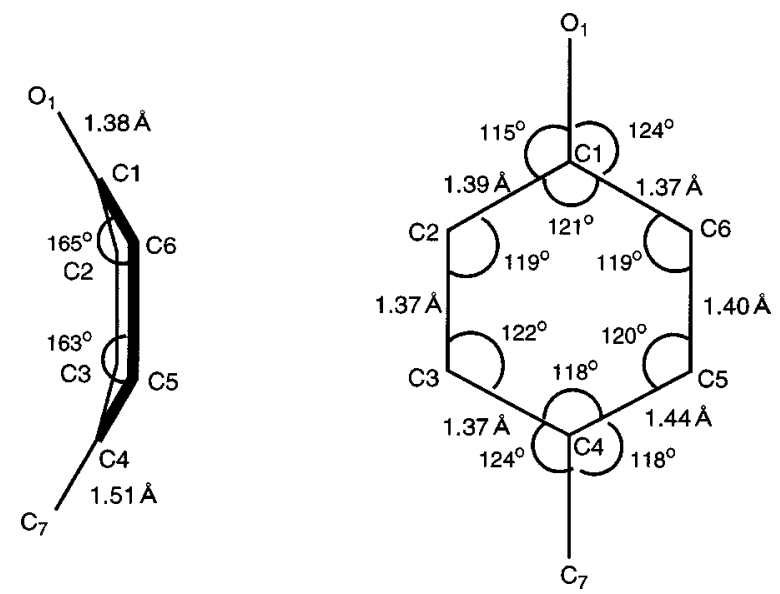

Fig. 13. Diagram of the benzene ring A of cavicularin (65) showing bond length, dihedral and inter-bond angles.

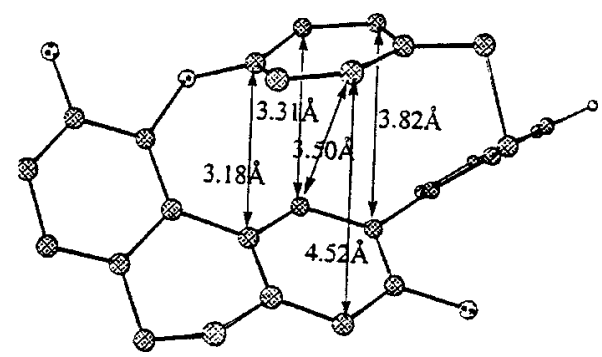

Fig. 14. Diagram of cavicularin (65) showing interatomic distance between A and D ring carbon.

65] accomplished the total synthesis of riccardin B (2) and marchantin A (8a) in twelve steps using the intramolecular Wadsworth-Emmons olefination and Wittig reaction. Iyoda et al. [66] also reported the total synthesis of riccardin B (2) using nickel-catalysed intramolecular coupling of the acyclic precursors possessing two chlorine atom. The same compound was also synthesized by Norgadi et al. [67] by using a combination of Ullmann, Wittig and Wurtz reactions. Marchantin B (9) and H (16) have also been 
synthesized by Ha et al. [68], applying the same methods as described above. By using Ullmann, Wittig and modified Wurtz reaction, Dienes et al. [69] accomplished the total synthesis of marchantin I (17). Keserü et al. [70] reported the total synthesis of plagiochin C (34) and D (35) by the same methodology as that of the total synthesis of marchantin and riccardin series. Recently, Fukuyama et al. [71,72] accomplished the total synthesis of plagiochins A (33), B (34) and D (35) by a combination of Ullmann, Wadsworth-Emmons, Still-Kelly reactions [71,72]. Norgadi reviewed the total synthesis of these types of compounds [73].

\section{Experimental}

\subsection{General}

The ${ }^{1} \mathrm{H}$ and ${ }^{13} \mathrm{C}$ NMR spectra were recorded at 600 and $150 \mathrm{MHz}$, respectively, on a Varian UNITY 600 spectrometer using $\mathrm{CDCl}_{3}$ with TMS as the internal standard unless otherwise stated. Measurements were performed at $25^{\circ} \mathrm{C}$ using $5 \mathrm{~mm}$ o.d. sample tubes. For the ${ }^{1} \mathrm{H}-{ }^{13} \mathrm{C}$ correlation experiment, pulsed field gradient heteronuclear single-quantum correlation (GHSQC)) was used $[74,75]$. The spectra were acquired with 1024 data points and 256 time increments with 8 transients per increment. The relaxation delay was $1.5 \mathrm{~s}$ and average ${ }^{1} J(\mathrm{C}-\mathrm{H})$ was set to $140 \mathrm{~Hz}$. The NMR spectra were also recorded on a JEOL JNM GX $400\left(400 \mathrm{MHz}\right.$ for ${ }^{1} \mathrm{H}, 100 \mathrm{MHz}$ for ${ }^{13} \mathrm{C}$ ) spectrometer using $\mathrm{CDCl}_{3}$ unless otherwise stated.

The mass spectra including high resolution mass spectra were taken with a JEOL JMS AX-500 spectrometer at $70 \mathrm{eV}$. CD spectra were recorded on a JASCO J-725 spectrometer with MeOH or EtOH. $[\alpha]_{\mathrm{D}}$ was measured in $\mathrm{MeOH}$ or $\mathrm{CHCl}_{3}$ on a JASCO DIP-1000 polarimeter. X-ray crystallographic analysis was carried out on a Mac Science MXC 18 diffractometer with $\mathrm{Cu} \mathrm{K} \alpha$ radiation. The structures were solved by direct method using CRYSTAN SIR 92 and refined by full-matrix least squares using CRYSTAN.

\subsection{Plant materials}

The liverworts were collected in Tokushima, in Shikoku Japan. The voucher specimens have been deposited at Faculty of Pharmaceutical Sciences, Tokushima Bunri University.

\subsection{Extraction and isolation}

The liverworts were air-dried and ground mechanically to give powders, which were extracted with methanol. Each methanol extract was filtered and the solvent evaporated to give a viscous material, which was chromatographed on silica gel (n-hexane/ethyl acetate gradient) and/or Sephadex LH 20 [methanol and chloroform $(1: 1)]$. Further purification of each fraction was carried out by preparative TLC and HLPC to give pure macrocyclic bis(bibenzyls).

\section{References}

[1] K. Müller, Hoppe Seyler's Ztschr. Physiol. Chem. 45 (1905), 299.

[2] S. Huneck and E. Klein, Phytochemistry 6 (1967), 383.

[3] Y. Asakawa, in: Progress in the Chemistry of Organic Natural Products, Vol. 42, W. Herz, H. Grisebach and G.W. Kirby, eds, Springer, Vienna, 1982, pp. 1-285. 
[4] Y. Asakawa, in: Progress in the Chemistry of Organic Natural Products, Vol. 65, W. Herz, G.W. Kirby, R.E. Moore, W. Steglich and Ch. Tamm, eds, Springer, Vienna, 1995, pp. 1-562.

[5] Y. Asakawa, Heterocycles 46 (1997), 795.

[6] H. Ding, Zhong guo Yao Yun Bao zi Zhi Wu. Kexue Jishu Chuban She, Shanghai, 1982, pp. 1-409.

[7] Y. Asakawa, in: Bryophytes: Their Chemistry and Chemical Taxonomy, D.H. Zinsmeister and R. Mues, eds, Clarendon Press, Oxford, 1990, pp. 369-410.

[8] Y. Asakawa, in: Bryophytes Development: Physiology and Biochemistry, R.N. Chopra and S.C. Bhatla, eds, CRC Press, Boca Raton, 1990, pp. 259-287.

[9] Y. Asakawa, in: Bioactive Natural Products: Detection, Isolation, and Structure Determination, S.M. Colegate and R.J. Molyneau, eds, CRC Press, Boca Raton, 1993, pp. 259-287.

[10] Y. Asakawa, J. Hattori Bot. Lab. 84 (1998), 91.

[11] Y. Asakawa, in: Phytochemicals in Human Health Protection, Nutrition, and Plant Defense, Vol. 33, J. Romeo, ed., Kluwer Academic/Plenum Publishers, New York, 1999, pp. 319-342.

[12] Y. Asakawa, M. Toyota, R. Matsuda, K. Takikawa and T. Takemoto, Phytochemistry 22 (1983), 1413.

[13a] Y. Asakawa, M. Toyota, Z. Taira, T. Takemoto and M. Kido, J. Org. Chem. 48 (1983), 2164.

[13b] M.S. Buchanan, M. Toyota, Y. Yoshida and Y. Asakawa, J. Hattori Bot. Lab. 83 (1997), 265.

[13c] F. Nagashima, S. Momosaki, Y. Watanabe, M. Toyota, S. Huneck and Y. Asakawa, Phytochemistry 41 (1996), 207.

[14] Y. Asakawa and R. Matsuda, Phytochemistry 21 (1982), 2143.

[15] Y. Asakawa, M. Tori, K. Takikawa, H.G. Krishnamurty and S.K. Kar, Phytochemistry 26 (1987), 1811.

[16] Y. Asakawa, K. Okada and G.W. Perold, Phytochemistry 27 (1988), 161.

[17] M. Toyota, F. Nagashima and Y. Asakawa, Phytochemistry 27 (1988), 2603.

[18] T. Hashimoto, Y. Asakawa, K. Nakashima and M. Tori, J. Hattori Bot. Lab. 74 (1993), 121

[19] T. Hashimoto, T. Yoshida, Y. Kan, S. Takaoka, M. Tori and Y. Asakawa, Tetrahedron Lett. 35 (1994), 909.

[20] T. Yoshida, T. Hashimoto, S. Takaoka, Y. Kan, M. Tori and Y. Asakawa, Tetrahedron 52 (1996), 14487.

[21] M. Toyota, T. Yoshida, J. Matsunami and Y. Asakawa, Phytochemistry 44 (1997), 293.

[22] A. Bardon, N. Kamiya, M. Toyota and Y. Asakawa, Phytochemistry 51 (1999), 281.

[23] T. Hashimoto, H. Irita and Y. Asakawa, J. Hattori Bot. Lab. 85 (1998), 239.

[24] A. Bardon, N. Kamiya, M. Toyota, S. Takaoka and Y. Asakawa, Phytochemistry 52 (1999), 1323.

[25] S. Kunz and H. Becker, Phytochemistry 31 (1992), 3981.

[26a] Y. Asakawa, M. Toyota, H. Bischler, E.O. Campbell and S. Hattori, J. Hattori Bot. Lab. 57 (1992), 383.

[26b] M. Toyota and Y. Asakawa, J. Hattori Bot. Lab. 86 (1999), 161.

[26c] M. Toyota, M. Konoshima, F. Nagashima, S. Hirata and Y. Asakawa, Phytochemistry 46 (1997), 293.

[27] M. Tori, M. Aoki and Y. Asakawa, Phytochemistry 35 (1994), 73.

[28] Y. Asakawa, Rev. Lationoamer. Quim. 14 (1984), 109.

[29] Y. Asakawa, M. Tori, T. Masuya and J.-P. Frahm, Phytochemistry 29 (1990), 1577.

[30a] M. Toyota, Ph.D. Thesis, Tokushima Bunri Univ., 1987, pp. 1-145.

[30b] M. Konoshima, Master Thesis, Tokushima Bunri Univ., 1998, pp. 1-105.

[31] M. Tori, M. Toyota, L.J. Harrison, K. Takikawa and Y. Asakawa, Tetrahedron Lett. 26 (1985), 4735.

[32a] S. Friederich, U.H. Maier, B. Deus-Neumann, Y. Asakawa and M.H. Zenk, Phytochemistry 50 (1999), 589.

[32b] S. Friederich, M. Rueffer, Y. Asakawa and M.H. Zenk, Phytochemistry 52 (1999), 1195.

[33] M. Tori, M. Toyota, L.J. Harrison, K. Takikawa and Y. Asakawa, Tetrahedron Lett. 26 (1985), 4735.

[34] H.-C. Wei and C.-L. Wu, J. Chem. Res. (S) (1991), 230.

[35] F. Nagashima, E. Nishioka, K. Kameo, C. Nakagawa and Y. Asakawa, Phytochemistry 30 (1991), 215.

[36] Y. Asakawa, X. Lin, K. Kondo and Y. Fukuyama, Phytochemistry 30 (1991), 4019.

[37] Y. Asakawa, J. Hattori Bot. Lab. 56 (1984), 215.

[38] Y. Asakawa, M. Toyota, E. Nakaishi and Y. Tada, J. Hattori Bot. Lab. 80 (1996), 271.

[39] F. Nagashima, H. Izumo, S. Takaoka, M. Tori and Y. Asakawa, Phytochemistry 37 (1994), 43.

[40] C.-L. Wu, Kor. J. Pharmacogn. 16 (1985), 243.

[41] C.-L. Wu and Y. Asakawa, J. Chin. Chem. Soc. 34 (1987), 219.

[42] J. Sporle, H. Becker, N.S. Allen and M.P. Gupta, J. Hattori Bot. Lab. 70 (1991), 151.

[43] T. Hashimoto, M. Tori, Y. Asakawa and Y. Fukazawa, Tetrahedron Lett. 28 (1987), 6925.

[44] H.-C. Wei, S.-J. Ma and C.-L. Wu, Phytochemistry 39 (1995), 91.

[45] M. Toyota and Y. Asakawa, J. Hattori Bot. Lab. 86 (1999), 161.

[46] C.-L. Wu, J. Chin. Chem. Soc. 39 (1992), 655.

[47] M. Toyota, M. Konoshima and Y. Asakawa, Phytochemistry 52 (1999), 105.

[48] T. Hashimoto, H. Ikeda, S. Takaoka, M. Tanaka and Y. Asakawa, Phytochemistry 52 (1999), 501

[49] S. Huneck, J.D. Connolly, D.S. Rycroft and N. Woods, J. Chem. Res. (S) (1988), 78.

[50] M. Tori, T. Masuya and Y. Asakawa, J. Chem. Res. (S) (1990), 36. 
[51] Y. Asakawa, T. Hashimoto, K. Akazawa and S. Huneck, J. Hattori Bot. Lab. 81 (1997), 243.

[52] T. Hashimoto, S. Kanayama, Y. Fukuyama, S. Takaoka, M. Tori and Y. Asakawa, Tetrahedron Lett. 35 (1994), 911.

[53] T. Hashimoto, T. Yoshida, S. Kanayama, S. Takaoka, Y. Kan, Y. Fukuyama, M. Tori and Y. Asakawa, 25th Symposium on the Chemistry of Natural Products, Kyoto, 1993, p. 353.

[54] T. Hashimoto, T. Yoshida, M. Tori, S. Takaoka and Y. Asakawa, 15th International Botanical Congress, Yokohama, 1993, p. 370.

[55] T. Hashimoto, S. Takaoka, Y. Kan, M. Tori and Y. Asakawa, Chem. Lett. (1996), 741.

[56] K. Nabeta, S. Ohkubo, R. Hozumi and K. Katoh, Phytochemistry 49 (1998), 1941.

[57] H. Anton, L. Kraut, R. Mues and M.I. Morales Z., Phytochemistry 46 (1997), 1069.

[58] U. Martini, J. Zapp and H. Becker, Phytochemistry 47 (1998), 89.

[59] T. Hashimoto, H. Irita, T. Takaoka, M. Tanaka and Y. Asakawa, Tetrahedron 3153 (2000).

[60] T. Yoshida, M. Toyota and Y. Asakawa, J. Nat. Prod. 60 (1997), 145.

[61] H. Toyota, T. Yoshida, Y. Kan, S. Takaoka and Y. Asakawa, Tetrahedron Lett. 37 (1996), 4745.

[62] A. Gottsegen, M. Norgadi, B. Vermes, M. Kajtar-Peredy and E. Bihatsi-Karsai, J. Chem. Soc. Perkin Trans. 1 (1990), 315.

[63] M. Kodama, Y. Shiobara, K. Matsumura and H. Sumitomo, Tetrahedron Lett. 26 (1985), 877.

[64] Y. Shiobara, H. Sumitomo, M. Tsukamoto, C. Harada and M. Kodama, Chem. Lett. (1985), 1587.

[65] M. Kodama, Y. Shiobara, H. Sumitomo, K. Matsumura, M. Tsukamoto and C. Harada, J. Org. Chem. 53 (1988), 72.

[66] M. Iyoda, M. Sakaitani, H. Otsuka and M. Oda, Tetrahedron Lett. 26 (1985), 4777.

[67] M. Norgadi, B. Vermes and M.K. Peredy, Tetrahedron Lett. 28 (1987), 2899.

[68] N.T.T. Ha, M. Norgadi, J. Brlik and A. Wolfner, J. Chem. Res. (S) (1991), 137.

[69] Z. Dienes, M. Norgadi, B. Vermes and M. Kajtar-Peredy, Liebigs Ann. Chem. (1989), 1141.

[70] G.M. Keserü, G. Mezey-Vandor, M. Nogradi, B. Vermes and M. Kaitar-Peredy, Tetrahedron 48 (1992), 913.

[71] Y. Fukuyama, K. Nakamura and M. Kodama, 112th Annual Meeting of Pharmaceutical Society of Japan, Fukuoka, Japan, 1992, Abstracts 2, p. 78.

[72] Y. Fukuyama, H. Yaso, K. Nakamura and M. Kodama, Tetrahedron Lett. 40 (1999), 105.

[73] G.M. Keseru and M. Nogradi, Natural Products Reports (1995), 69.

[74] A.L. Davis, J. Keller, E.D. Laue and D. Moskau, J. Mag. Reson. 98 (1992), 207.

[75] G.W. Vuister, J.R. Cabllo and P.C.M. Van Zijl, J. Mag. Reson. 100 (1992), 215. 


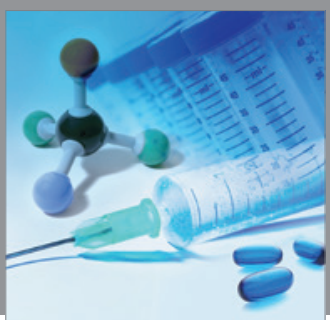

International Journal of

Medicinal Chemistry

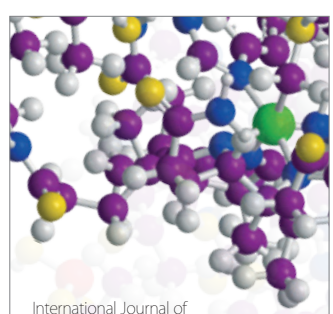

Carbohydrate Chemistry

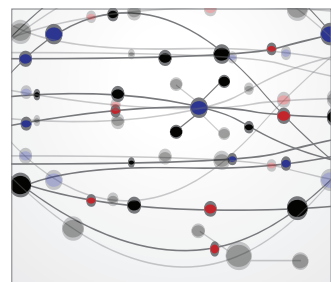

The Scientific World Journal
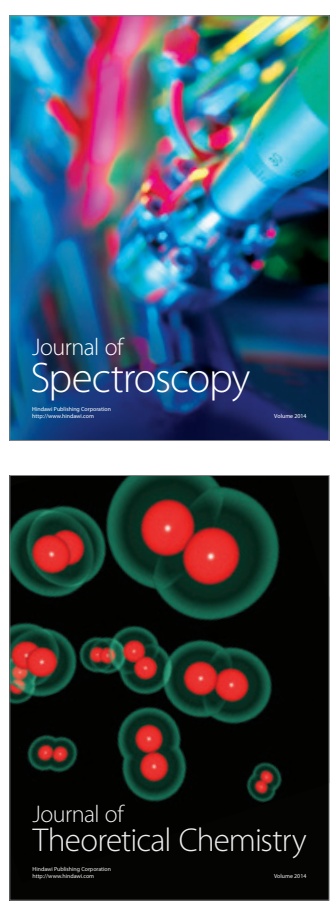
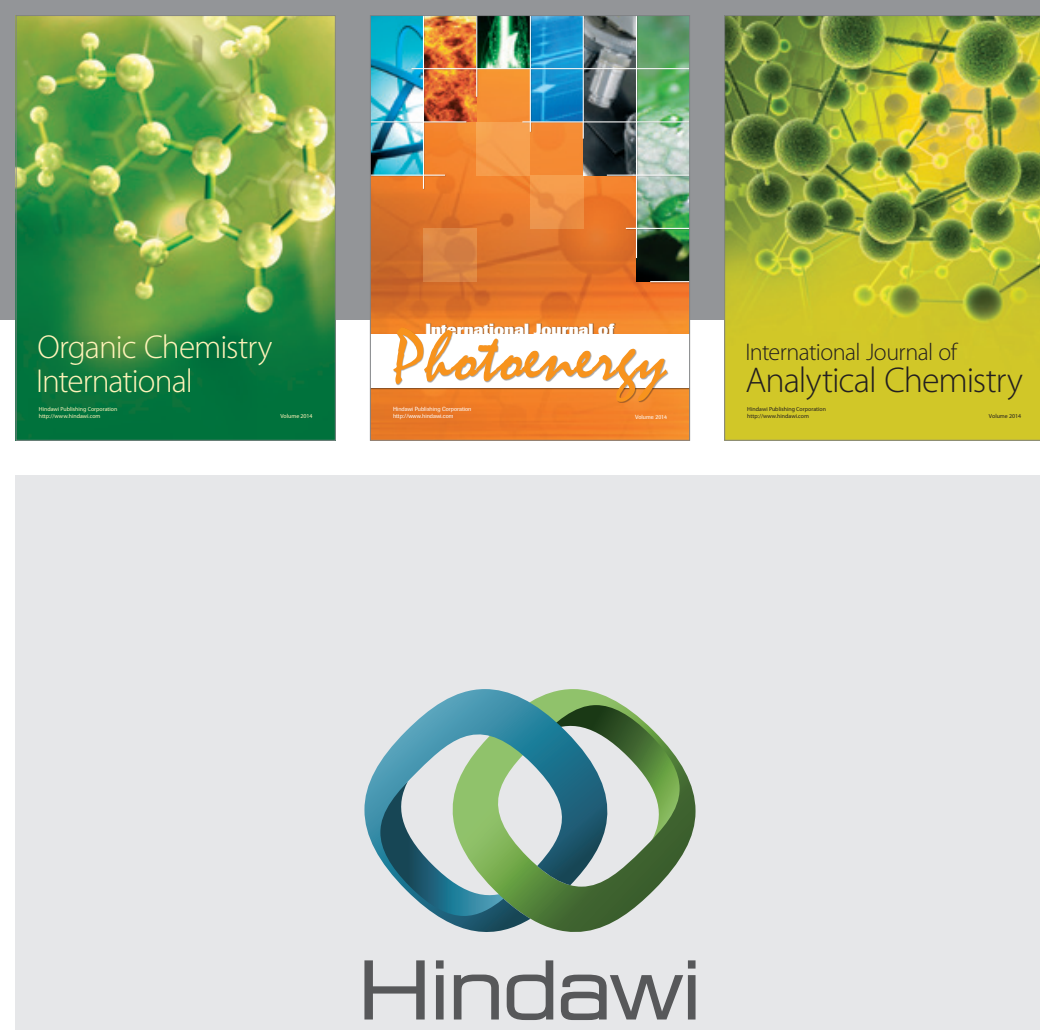

Submit your manuscripts at

http://www.hindawi.com
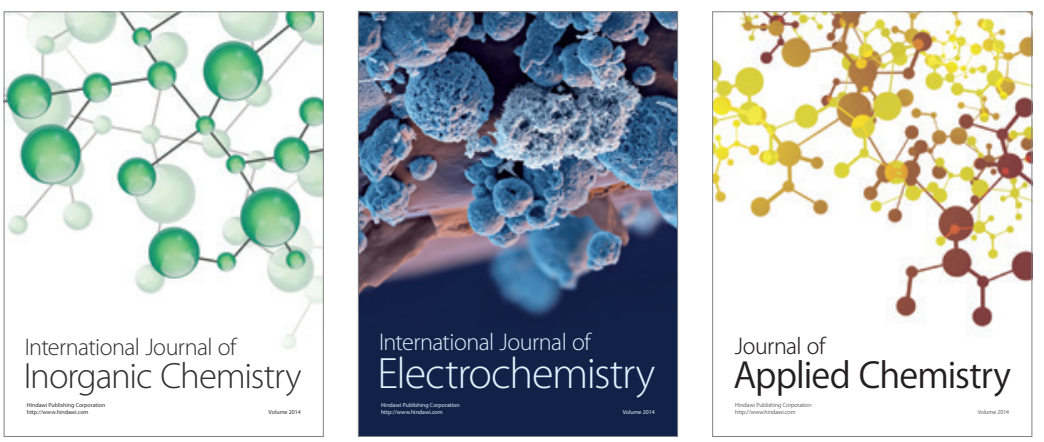

Journal of

Applied Chemistry
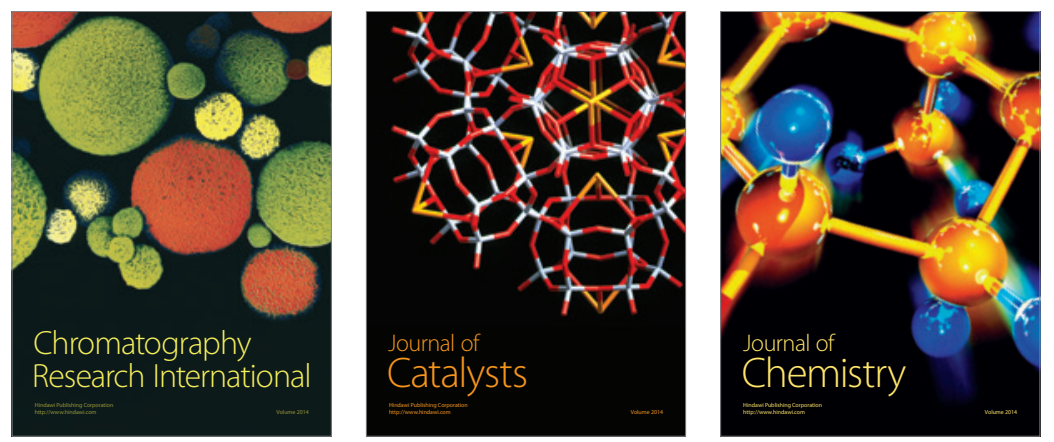
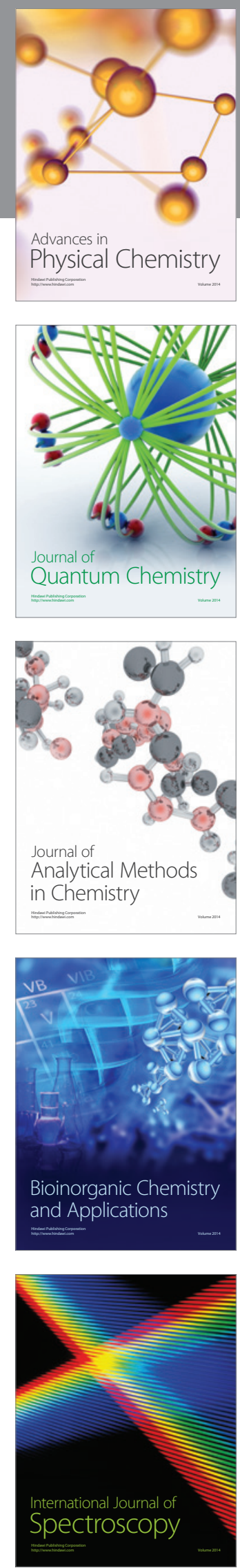